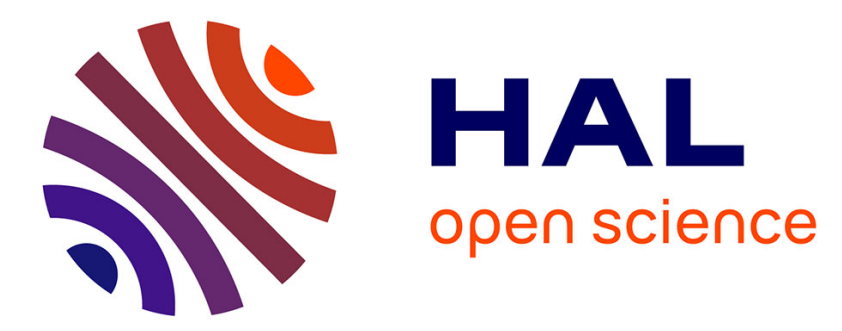

\title{
Nutrient dynamics under different ocean acidification scenarios in a low nutrient low chlorophyll system: the Northwestern Mediterranean Sea
}

Justine Louis, Cecile Guieu, Frédéric Gazeau

\section{- To cite this version:}

Justine Louis, Cecile Guieu, Frédéric Gazeau. Nutrient dynamics under different ocean acidification scenarios in a low nutrient low chlorophyll system: the Northwestern Mediterranean Sea. Estuarine, Coastal and Shelf Science, 2017, 186 (A), pp.30-44. 10.1016/j.ecss.2016.01.015 . hal-01254357

\section{HAL Id: hal-01254357 \\ https: / hal.sorbonne-universite.fr/hal-01254357}

Submitted on 12 Jan 2016

HAL is a multi-disciplinary open access archive for the deposit and dissemination of scientific research documents, whether they are published or not. The documents may come from teaching and research institutions in France or abroad, or from public or private research centers.
L'archive ouverte pluridisciplinaire HAL, est destinée au dépôt et à la diffusion de documents scientifiques de niveau recherche, publiés ou non, émanant des établissements d'enseignement et de recherche français ou étrangers, des laboratoires publics ou privés. 


\section{Nutrient dynamics under different ocean acidification scenarios in a low nutrient low chlorophyll system: the Northwestern Mediterranean Sea}

Louis J. ${ }^{1 *}$, Guieu C. ${ }^{1}$ and Gazeau F. ${ }^{1}$

[1] Sorbonne Universités, UPMC Univ Paris 06, CNRS, UMR 7093, LOV, Observatoire océanologique, F-06230, Villefranche-sur-mer, France

*Corresponding author: justine.louis35@gmail.com

Highlights:

- Mesocosm experiments performed in two Mediterranean sites during two seasons

- Contrasted nutrient stoichiometry in surface waters in summer and winter

- Dissolved organic pool was a large stable fraction of $\mathrm{N}$ and $\mathrm{P}$ in summer and winter

- $\mathrm{CO}_{2}$ had no effect on nutrient dynamics that was mostly biologically controlled

Keywords: ocean acidification; plankton community; mesocosm experiments; nutrient dynamics; nitrogen; phosphorus; iron; stoichiometry; Oligotrophy; Mediterranean Sea 


\section{Abstract}

Two pelagic mesocosm experiments were conducted to study the impact of ocean acidification on Mediterranean plankton communities. A first experiment took place in summer 2012 in the Bay of Calvi (France) followed by an experiment in winter 2013 in the Bay of Villefranche (France) under pre-bloom conditions. Nine mesocosms were deployed: three served as controls and six were acidified in a targeted partial pressure of $\mathrm{CO}_{2}\left(p \mathrm{CO}_{2}\right)$ gradient from 450 to $1250 \mu \mathrm{atm}$. The evolution of dissolved organic and inorganic nutrient concentrations was observed using nanomolar techniques. The experiments were characterized by a large contribution of organic nutrients to nutrient pools and contrasting in situ conditions with an inorganic N / P ratio of 1.7 in summer and of 117 in winter. In the Bay of Calvi, initial conditions were representative of the summer oligotrophic Mediterranean Sea. While inorganic phosphate concentrations were depleted during both experiments, in situ inorganic nitrogen concentrations were higher in winter. However, nitrate was rapidly consumed in winter in all mesocosms during the acidification phase, leading to a decrease in $\mathrm{N} / \mathrm{P}$ ratio to 13. During these first mesocosm experiments conducted in a low nutrient low chlorophyll area, nutrient dynamics were insensitive to $\mathrm{CO}_{2}$ enrichment, indicating that nutrient speciation and related biological processes were likely not impacted. During both experiments, nitrate and phosphate dynamics were controlled by the activity of small species that are favored in low nutrient conditions. In contrast to the theoretical knowledge, no increase in iron solubility at high $p \mathrm{CO}_{2}$ was observed. 


\section{Introduction}

Since the beginning of the industrial era, the atmospheric carbon dioxide $\left(\mathrm{CO}_{2}\right)$ level has increased by nearly 40\% (from 280 to 390 ppm in 2011; Hartmann et al., 2013) and may reach between $\sim 450$ and $\sim 1000$ ppm by 2100 depending on the considered future emission scenario (Collins et al., 2013). As the ocean absorbs about a quarter of total anthropogenic $\mathrm{CO}_{2}$ emissions (Le Quéré et al., 2014), the increase in $\mathrm{CO}_{2}$ dissolved in seawater leads to an increase in seawater acidity (decrease in $\mathrm{pH}$ ). Surface ocean $\mathrm{pH}$ has already declined by approximately 0.1 since the beginning of the industrial era (Orr, 2005) and is expected to decrease an additional 0.06 to 0.32 by the end of this century depending on the considered $\mathrm{CO}_{2}$ emission scenario (Ciais et al., 2013). Although the chemical forms of compounds such as macro- and micro-nutrients in the ocean are controlled by multiple environmental factors including $\mathrm{pH}$, only a restricted number of studies have addressed the impact of ocean acidification on nutrient dynamics and its consequences on biological activity.

Following established theoretical equilibriums of dissolved inorganic phosphate and ammonium $\left(\mathrm{NH}_{4}^{+}\right)$in seawater as a function of $\mathrm{pH}$ (i.e. Zeebe and Wolf-Gladrow, 2001), a decrease in surface ocean $\mathrm{pH}$ expected to occur this century will lead to a decrease of phosphate $\left(\mathrm{PO}_{4}{ }^{3-}\right)$ concentrations by up to $80 \%$ (and increase in $\mathrm{HPO}_{4}{ }^{2-}$ ) and an alteration of the $\mathrm{NH}_{4}{ }^{+} / \mathrm{NH}_{3}$ equilibrium. Therefore, ocean acidification could directly affect the chemical speciation of phosphorus and nitrogen with impacts on their bioavailability and stoichiometry.

In addition to $\mathrm{pH}$ equilibrium reactions, ocean acidification can impact biological processes and indirectly shift nutrient cycles. In the case of nitrogen, an increase in the partial pressure of $\mathrm{CO}_{2}\left(p \mathrm{CO}_{2}\right)$ could (1) enhance nitrogen fixation (e.g. Hutchins et al., 2007) and

(2) reduce the rate of marine nitrification (e.g. Beman et al., 2011). The alteration of the $\mathrm{NH}_{4}^{+}$ $/ \mathrm{NO}_{3}{ }^{-}$ratio and the increasing trend toward P-limitation could ultimately impact primary 
production and phytoplankton community structure (CIESM, 2008; Hutchins et al., 2009). For example, Romero et al. (2012) showed that waters rich in $\mathrm{NH}_{4}{ }^{+}$favor the growth of small autotrophic species and heterotrophic bacteria while $\mathrm{NO}_{3}{ }^{-}$mostly favor diatom growth.

The organic fraction of dissolved nutrients (dissolved organic nitrogen: DON and dissolved organic phosphorus: DOP) can represent a large source of $\mathrm{P}$ and $\mathrm{N}$ for microorganisms in oligotrophic areas (e.g. Jackson and Williams, 1985; Karl and Bjorkman, 2002; Bronk, 2007). Regarding DOP, most of its compounds cannot be used by phytoplankton directly, unless specific enzymes (e.g. alkaline phosphatase) are produced to hydrolyze DOP into $\mathrm{PO}_{4}{ }^{3-}$ (Holland et al., 2005; Dyhrman and Ruttenberg, 2006). These hydrolysis reactions are sensitive to $\mathrm{pH}$ with the consequence that a change in $\mathrm{pH}$ could alter the bioavailability of DOP in seawater (Doney et al., 2009).

Furthermore, decreases in ocean $\mathrm{pH}$ theoretically increase the proportion of free dissolved trace metals and increase metal solubility (Millero, 1998). This would lead to substantial increases in the total bioavailable fraction of many trace elements and result in toxic concentrations for marine microorganisms (Raven et al., 2005). Several studies have shown that a decrease in ocean $\mathrm{pH}$ enhances the solubility of $\mathrm{Fe}(\mathrm{III})$, a form of iron that is bioavailable for phytoplankton (e.g. Liu and Millero, 2002; Millero et al., 2009). Iron speciation is largely controlled by organic complexation and photochemical processes (Breitbarth et al., 2010a and ref within). A decrease of $\mathrm{pH}$ below 8 favors the iron complexation with organic ligands against the precipitated form $\mathrm{Fe}(\mathrm{OH})_{3}$ (De Rijck and Schrevens, 1998). The effect of ocean acidification on Fe(III)-organic complexation needs further investigations (Hoffmann et al., 2012). Shi et al. (2010) have shown that depending on the nature of the chelating agent, a pH decrease could enhance the solubility of Fe by 
maintaining Fe(III) binding and affect the chemical speciation of Fe by favoring Fe chelated by organic compounds rather than its oxy-hydroxide form $\left(\mathrm{Fe}(\mathrm{OH})_{3}\right)$.

Ligand production is facilitated by phytoplankton dissolved organic matter (DOM) production. Enhanced release of DOM with increasing $p \mathrm{CO}_{2}$ (i.e. Engel, 2002) could, as a feedback, increase iron binding and make it more bioavailable for primary production. This has recently been shown in in situ mesocosm experiments conducted as part of the Pelagic Ecosystem $\mathrm{CO}_{2}$ Enrichment project (PeECE) in Bergen, Norway (Breitbarth et al., 2010b).

Most studies investigating the impact of ocean acidification on pelagic ecosystems have been performed in laboratories but, during the last decade, several mesocosm experiments have been conducted, for instance as part of the PeECE project and the European Project on Ocean Acidification (EPOCA; i.e. Engel et al., 2005; Grossart et al., 2006; Schulz et al., 2008; Riebesell et al., 2013). Mesocosms offer the advantage to follow the response of pelagic communities to an environmental driver under close-to-natural environmental conditions. The above-mentioned mesocosm experiments have been mostly performed in nutrient-replete cold waters. However, a large portion of the open ocean is characterized by low-nutrient, low-chlorophyll (LNLC) conditions. To our knowledge, no ocean acidification mesocosm study has been conducted under these limiting conditions as observed in the Mediterranean Sea.

The Mediterranean Sea is one of the most nutrient-poor waters in the world with a trophic status varying from oligotrophic-mesotrophic in the Northwestern Mediterranean to extremely oligotrophic in the eastern basin (Moutin and Rimbault, 2002; Mermex Group, 2011 and references within). The Mediterranean Sea is in general a sink for atmospheric $\mathrm{CO}_{2}$ (D'Ortenzio et al., 2008). As this region is relatively more alkaline than the open ocean, it absorbs relatively more anthropogenic $\mathrm{CO}_{2}$ and is a significant source of $\mathrm{CO}_{2}$ for the Atlantic 
ocean (Ait-Ameur and Goyet, 2006). Long-term data series of carbonate properties and ocean acidification trends in the Mediterranean Sea are scarce. However, current interpolation suggests that $\mathrm{pH}$ may have already declined by 0.15 in some areas of the surface Mediterranean Sea (Touratier and Goyet, 2011).

The objective of the present study is to assess the effect of ocean acidification on nutrient (Fe, $\mathrm{N}$ and $\mathrm{P}$ ) dynamics in a nutrient-depleted system, limited or co-limited by $\mathrm{P}$ and N availability (Tanaka et al., 2011): the Mediterranean Sea. Two mesocosm experiments have been conducted in the Northwestern Mediterranean Sea during contrasting periods in terms of biogeochemical conditions and trophic status. These experiments were conducted in the framework of European Mediterranean Sea Acidification in a Changing Climate project (MedSeA; $\underline{\text { www.medsea-project.eu }}$. In this paper, we report on the evolution of nutrient concentrations, under both dissolved inorganic and organic forms, and discuss the potential impact of ocean acidification on nutrient dynamics in LNLC ecosystems. 


\section{Material and methods}

\subsection{Experimental setup and sampling}

The first mesocosm experiment was performed in the Bay of Calvi (BC; Corsica, France) during summer (June-July 2012), and the second experiment was conducted in the Bay of Villefranche (BV; France) during winter (February-March 2013). A complete description of the sites, experimental setup, initial conditions and evolution of the core parameters is given in Gazeau et al. (submitted, this issue-a). Briefly, for each experiment, nine mesocosms (2.5 $\mathrm{m}$ in diameter, $12 \mathrm{~m}$ depth and $\sim 50 \mathrm{~m}^{3}$ in total volume) were deployed during 20 (BC) and 11 days (BV). Mesocosm bags were made of plastic material (polyethylene mixed with vinyl acetate) with nylon mesh to allow a maximum resistance and light penetration. In order to avoid atmospheric deposition, the top of the mesocosms were covered with UV-transparent ethylene tetrafluoroethylene (ETFE) roofs, except for periods of sampling during which the roofs were partially opened. Three unperturbed mesocosms were used as controls $(\mathrm{C} 1, \mathrm{C} 2$ and $\mathrm{C} 3)$ and six mesocosms were enriched with $\mathrm{CO}_{2}$ to obtain a gradient of $p \mathrm{CO}_{2}$ levels ( $\mathrm{P} 1$ to $\mathrm{P} 6$ ). Targeted $p \mathrm{CO}_{2}$ levels were obtained via addition of 75 to $>300 \mathrm{~L}$ of $\mathrm{CO}_{2}$-saturated water into mesocoms. A diffusing system was used to ensure a perfect mixing of this $\mathrm{CO}_{2}$-saturated seawater inside the mesocosms. In order to minimize the stress induced by the addition of large quantities of acid water, the acidification of the mesocosms was performed over the course of 4 days. Control mesocosms presented initial $p \mathrm{CO}_{2}$ levels of 450 and $350 \mu \mathrm{atm}$ in $\mathrm{BC}$ and $\mathrm{BV}$, respectively. In $\mathrm{BC}$, the six targeted elevated $p \mathrm{CO}_{2}$ levels were P1: 550, P2: 650, P3: 750, P4: 850, P5: 1000 and P6: $1250 \mu$ atm. In BV, the targeted levels were P1: 450, P2: 550, P3: 750, P4: 850, P5: 1000 and P6: $1250 \mu$ atm. Mesocosms were anchored in clusters of 3, each cluster containing one control mesocosm accompanied by a medium and a high $p \mathrm{CO}_{2}$ level (cluster 1: $\mathrm{C} 1, \mathrm{P} 1, \mathrm{P} 4$; cluster 2: C2, P2, P5 
and cluster 3: C3, P3, P6). On June $24^{\text {th }} 2012$ (in BC) and on February $21^{\text {st }} 2013$ (in BV), the targeted $p \mathrm{CO}_{2}$ levels were reached and the experiments started (day 0). Daily depth-integrated sampling $(0-10 \mathrm{~m})$ was performed using $5 \mathrm{~L}$ Hydro-Bios integrated water samples in the nine mesocosms and in the external environment (OUT) in order to follow the dynamics of each considered parameter in natural free waters.

Seawater samples for total alkalinity $\left(A_{\mathrm{T}} ; 500 \mathrm{~mL}\right)$ measurements were filtered on $\mathrm{GF} / \mathrm{F}$ membranes while samples for total inorganic carbon $\left(C_{\mathrm{T}} ; 120 \mathrm{~mL}\right)$ measurements were immediately inoculated with $20 \mu \mathrm{L}$ of a saturated solution of mercuric chloride $\left(\mathrm{HgCl}_{2}\right)$. Both parameters were analyzed within one day of collection. For pigments, $2 \mathrm{~L}$ of sampled seawater were filtered onto GF/F membranes. Filters were immediately frozen in liquid nitrogen and stored at $-80^{\circ} \mathrm{C}$ pending analysis at the Laboratoire d'Océanographie de Villefranche (France). Samples for the determination of heterotrophic prokaryote abundances were collected every second day, immediately fixed with $0.2 \mu \mathrm{m}$ pre-filtered $25 \%$ glutaraldehyde ( $0.5 \%$ final concentration), kept at $4{ }^{\circ} \mathrm{C}$ for approximately $30 \mathrm{~min}$, deep frozen in liquid nitrogen and stored at $-80{ }^{\circ} \mathrm{C}$ until enumeration.

For dissolved inorganic and organic nutrients $\left(\mathrm{NO}_{\mathrm{x}}, \mathrm{PO}_{4}{ }^{3-}, \mathrm{DFe}, \mathrm{DON}\right.$ and DOP), bulk seawater samples were collected in $1 \mathrm{~L}$ bottles previously rinsed 3 times with sampled seawater. Shortly after sampling, samples were filtered onto $0.2 \mu \mathrm{m}$ polycarbonate filters (Nucleopore, Whatman) under a laminar flow bench. Filters were cleaned with a 5\% hydrochloric acid $(\mathrm{HCl})$ suprapure solution for $30 \mathrm{~min}$, rinsed 20 times with ultrapure water, cleaned again with $1 \% \mathrm{HCl}$ suprapure solution for $24 \mathrm{~h}$ and finally rinsed and kept in ultrapure water in a Teflon vial. After filtration, samples for $\mathrm{NO}_{\mathrm{x}}, \mathrm{PO}_{4}{ }^{3-}, \mathrm{DFe}$, were kept in 60 $\mathrm{mL}$ polyethylene bottles, previously cleaned following trace-metal clean procedures (Bruland et al., 1979), and then acidified to $\mathrm{pH}<2$ with $\mathrm{HCl}$ ultrapure, following the recommendations 
of Pulido-Villena et al. (2010). Samples for the determination of DON and DOP were not acidified but directly irradiated (see section 2.2.2 and 2.2.3). Data for DON and DOP were not available at the end of both experiments due to an irradiation defect (BC) and bad weather conditions (BV).

\subsection{Analytical method}

\subsubsection{Carbonate chemistry, chlorophyll $a$ and heterotrophic prokaryote abundance}

$A_{\mathrm{T}}$ was determined potentiometrically and $C_{\mathrm{T}}$ was determined using an inorganic carbon analyser (AIRICA, Marianda $\odot$, Kiel, Germany) coupled to an infrared gas analyser (LI-COR@ $\odot$ 6262). More detailed analytical protocols are given in Gazeau et al. (submitted, this issue-a). All parameters of the carbonate chemistry were determined from $C_{\mathrm{T}}, A_{\mathrm{T}}$, temperature and salinity using the R package seacarb (Lavigne et al., 2014). Chlorophyll $a$ (Chla) measurements were performed by high performance liquid chromatography (HPLC, following the protocol described in Gazeau et al. (submitted, this issue-b). The abundance of free-living heterotrophic prokaryotes (HP) was estimated by flow cytometry as described in Celussi et al. (in press, this issue).

\subsubsection{Dissolved inorganic phosphorus $\left(\mathrm{PO}_{4}{ }^{3-}\right)$ and dissolved organic phosphorus (DOP)}

A Liquid Waveguide Capillary Cell (LWCC), made of quartz capillary tubing, was used to manually analyze $\mathrm{PO}_{4}{ }^{3-}$. The LWCC was connected to a spectrophotometer and measurements were performed in the visible at $710 \mathrm{~nm}$. This spectrometric method is based on Murphy and Riley's molybdenum blue method and uses two reagents: (1) a mixed reagent composed of an ammonium molybdate solution $\left(40 \mathrm{~g} \mathrm{~L}^{-1}\right.$ in ultrapure water) and an antimony potassium tartrate solution ( $3 \mathrm{~g} \mathrm{~L}^{-1}$ in ultrapure water) in $5 \mathrm{~N}$ sulfuric acid solution, and (2) an ascorbic acid solution $\left(18 \mathrm{~g} \mathrm{~L}^{-1}\right.$ in 2/3 of ultrapure water and 1/3 of SDS surfactant solution; Zimmer and Cutter, 2012; Zhang and Chi, 2002). The LWCC was $2.5 \mathrm{~m}$ long in order to 
decrease the limit of detection to $1 \mathrm{nM}$. The repeatability and reproducibility standard deviations were around $4.8 \%$ and $7 \%$, respectively. Phosphate concentrations $\left(\left[\mathrm{PO}_{4}{ }^{3-}\right]\right)$ were calculated using a calibration method in ultrapure water, following the Beer-lambert's law, and validated by a standard addition method $\left(\mathrm{t}_{\text {student }}=0.988, \mathrm{n}=25, \mathrm{p}_{\text {value }}=0.30, \alpha=0.05\right)$.

To determine DOP concentrations ([DOP $\left.]_{\mathrm{UV}}\right)$, samples were irradiated by ultra-violet light (UV) using the 705 UV Digester (Metrohm). Samples were transferred into $10 \mathrm{~mL}$ (a total of $20 \mathrm{~mL}$ was irradiated for each sample) quartz tubes and irradiated during $90 \mathrm{~min}$ with a mercury vapor lamp, according to the method UV light photooxidation described by Armstrong and Tibbitts (1968). With the standard molybdenum blue method of Murphy and Riley, the concentration of total dissolved phosphorus [TDP] was measured in irradiated samples. [DOP $]_{\mathrm{UV}}$ was then determined by subtracting $\left[\mathrm{PO}_{4}{ }^{3-}\right]$ from [TDP].

\subsubsection{Dissolved inorganic nitrogen $\left(\mathrm{NO}_{\mathrm{x}}\right)$ and dissolved organic nitrogen (DON)}

The exact same protocol (and equipment) as described by Louis et al. (2015) was used to determine dissolved inorganic nitrogen concentrations. Briefly, the analysis of $\mathrm{NO}_{\mathrm{x}}\left(=\mathrm{NO}_{3}{ }^{-}\right.$ $+\mathrm{NO}_{2}^{-}$) was performed by a spectrometric method in the visible at $540 \mathrm{~nm}$, with a $1 \mathrm{~m}$ LWCC. This method is based on the colored reaction between $\mathrm{NO}_{2}{ }^{-}$and 2 reagents (sulfanilamide and NED) to form a pink azo compound. Previously, samples were passed through a copperized cadmium column to reduce $\mathrm{NO}_{3}{ }^{-}$to $\mathrm{NO}_{2}{ }^{-}$and determine $\mathrm{NO}_{\mathrm{x}}$ concentrations $\left(\left[\mathrm{NO}_{\mathrm{x}}\right]\right)$ using a calibration curve in ultrapure water. The limit of detection was $\sim 10 \mathrm{nM}$ and the reproducibility was $\sim 6 \%$ (tested using a reference solution, CertiPUR, Merck; $\left.\mathrm{t}_{\text {student }}=0.263, \mathrm{n}=7, \mathrm{p}_{\text {value }}=0.80, \alpha=0.05\right)$.

Similar to DOP, DON concentrations ([DON $]_{\mathrm{UV}}$ ) were determined by the irradiation UV method during which DON and all reduced inorganic ions, such as $\mathrm{NO}_{2}^{-}$, are oxidized to $\mathrm{NO}_{3}{ }^{-}$. Using the same spectrometric method used to analyze $\mathrm{NO}_{\mathrm{x}}$ (see section above), the 
concentration of total dissolved nitrogen [TDN] was measured, and [DON] $]_{\mathrm{Uv}}$ was calculated by subtracting $\left[\mathrm{NO}_{\mathrm{x}}\right]$ from $[\mathrm{TDN}]$.

\subsubsection{Dissolved iron (DFe)}

DFe concentrations were measured by flow injection with online preconcentration and chemiluminescence detection using the exact protocol, instrument, and analytical parameters as described by Bonnet and Guieu (2006). Briefly, our flow injection analysis and chemiluminescence detection (FIA-CL) instrument is based on the method described by Obata et al. (1993). In order to quantify the low DFe concentration [DFe] in seawater, samples (with $\mathrm{pH}$ adjusted to $~ 5$ ) were passed through MAF-8HQ (8-quinolinol-immobilized fluoride containing metal alkoxide glass) resin column to selectively collect and preconcentrate $\mathrm{DFe}$. After elution of DFe by a $\mathrm{HCl}$ solution, the eluent was mixed with a luminol solution $(0.74 \mathrm{M})$, an ammonium hydroxide solution $(1 \mathrm{M})$ and a hydrogen peroxide $\left(\mathrm{H}_{2} \mathrm{O}_{2}\right)$ solution $(0.7 \mathrm{M})$. A luminescence reaction occurs between the luminol and $\mathrm{H}_{2} \mathrm{O}_{2}$, catalyzed with DFe in alkaline conditions. Two distinct seawater reference materials were used to control for analytical accuracy: NASS-5 (North Atlantic Surface Seawater) and D1-508 (SAFe reference seawater) with measured [DFe] of $3.74 \pm 0.19 \mathrm{nM}$ and $0.65 \pm 0.03 \mathrm{nM}$ respectively in good agreement with consensus values $(3.763 \pm 0.001$ and $0.67 \pm 0.04 \mathrm{nM}$ respectively). The repeatability and reproducibility were lower than $10 \%$, and the detection limit was $\sim 20 \mathrm{pM}$. Data of [DFe] are only available for the experiment in BV.

\subsection{Data availability}

Data collected during both experiments are freely available on Pangaea, Bay of Calvi (BC): http://doi.pangaea.de/10.1594/PANGAEA.810331 and Bay of Villefranche (BV): http://doi.pangaea.de/10.1594/PANGAEA.835117. 


\subsection{Statistical analysis}

In order to test for ocean acidification effects on $\left[\mathrm{NO}_{\mathrm{x}}\right],\left[\mathrm{PO}_{4}{ }^{3-}\right],[\mathrm{DOP}]_{\mathrm{UV}},[\mathrm{DON}]_{\mathrm{UV}}$ and [DFe], the measured concentration in each perturbed mesocosm for each sampling date was subtracted from the average of concentrations in the 3 controls at that time-point. The relative mean deviation (MD, expressed as a \%) for each treatment and time-point was obtained by dividing that value by the average concentration in the 3 controls. A simple linear regression model was used to test $\mathrm{MD}$ variations as a function of delta $p \mathrm{CO}_{2}$, which corresponds to the difference of $p \mathrm{CO}_{2}$ level between the treatments and the 3 controls at each time-point. A significant linear trend between $\mathrm{MD}$ and $p \mathrm{CO}_{2}$ was considered when $\mathrm{p}_{\mathrm{value}}<$ 0.05 (Fisher'test). Above this threshold, we assumed that acidification had no linear effect on nutrient dynamics. All regressions were conducted using the R software. 


\section{Results}

\subsection{Initial conditions}

Table 1 presents the initial conditions (day 0) of $p \mathrm{CO}_{2}$ and $\mathrm{pH}_{\mathrm{T}}$ (on the total scale) in the nine mesocosms during both experiments. In $\mathrm{BC}$, the initial $p \mathrm{CO}_{2}$ in control mesocosms was $467 \pm 5 \mu$ atm corresponding to a $\mathrm{pH}_{\mathrm{T}}$ of 8.02 . At the start of the experiment, perturbed $p \mathrm{CO}_{2}$ levels were close to the targeted levels and ranged from 609 to $1353 \mu$ atm (P1 to P6) corresponding to a $\mathrm{pH}_{\mathrm{T}}$ gradient from 7.92 to 7.61 . In $\mathrm{BV}$, initial $p \mathrm{CO}_{2}$ levels in control mesocosms were lower than in $\mathrm{BC}$, with an average $p \mathrm{CO}_{2}$ of $358 \pm 17 \mu$ atm corresponding to a $\mathrm{pH}_{\mathrm{T}}$ of 8.12. Initial $p \mathrm{CO}_{2}$ levels in perturbed mesocosms were close to the targeted levels and ranged from $494 \mu$ atm (P1) to $1250 \mu$ atm (P6) corresponding to a $\mathrm{pH}_{\mathrm{T}}$ ranging from 8.0 to 7.63 .

Initial nutrient and Chla concentrations in $\mathrm{BC}$ and in $\mathrm{BV}$ inside control mesocosms and outside are presented in Table 2. In BC, [Chla] was higher outside $\left(0.12 \mu \mathrm{g} \mathrm{L}^{-1}\right)$ than inside mesocosms $\left(0.06 \pm 0.01 \mu \mathrm{g} . \mathrm{L}^{-1}\right)$. The same holds true for $\left[\mathrm{PO}_{4}{ }^{3-}\right](35$ vs $22 \pm 3 \mathrm{nM})$. In control mesocosms, $[\mathrm{DOP}]_{\mathrm{UV}}$ was similar to $\left[\mathrm{PO}_{4}{ }^{3-}\right](23 \pm 4 \mathrm{nM})$, while lower values were measured outside $(\sim 16 \mathrm{nM})$. $\mathrm{DON}_{\mathrm{UV}}$ represented the largest dissolved $\mathrm{N}$ pool with concentrations of 2 and $3.6 \pm 2.1 \mu \mathrm{M}$ inside and outside control mesocosms respectively, while $\left[\mathrm{NO}_{\mathrm{x}}\right]$ was lower with no difference between outside and inside control mesocosms $(0.05 \mu \mathrm{M} v s 0.06 \pm 0.01 \mu \mathrm{M})$.

In BV, [Chla] was much higher than in BC with initial values of $1.15 \pm 0.06 \mu \mathrm{g} \mathrm{L}^{-1}$ inside control mesocosms and $0.95 \mu \mathrm{g} \mathrm{L}^{-1}$ outside. This was also the case for [DOP $]_{\mathrm{UV}}$ with values of $45 \pm 1 \mathrm{nM}$ inside control mesocosms and $48 \mathrm{nM}$ outside. Regarding $\left[\mathrm{PO}_{4}{ }^{3-}\right]$, values were lower in $\mathrm{BV}$ than in $\mathrm{BC}$ and were similar inside and outside control mesocosms $(\sim 10$ $\mathrm{nM}) .[\mathrm{DON}]_{\mathrm{UV}}$ were also similar outside and inside control mesocoms at 4.0 and $3.6 \pm 0.7$ 
$\mu \mathrm{M}$ respectively. In contrast, $\left[\mathrm{NO}_{\mathrm{x}}\right]$ was higher in $\mathrm{BV}$ than in $\mathrm{BC}$ and a difference between OUT and control mesocosms was observed $(1.17$ vs $0.13 \pm 0.03 \mu \mathrm{M})$. [DFe] was $1.2 \mathrm{nM}$ inside and outside control mesocosms.

\subsection{Environmental and experimental conditions during the summer experiment in the Bay of Calvi}

In $\mathrm{BC}$, in the perturbed mesocosms, as no further addition of $\mathrm{CO}_{2}$-saturated seawater was performed, $p \mathrm{CO}_{2}$ levels slightly decreased after the acidification phase over the course of the experiment, especially for high $\mathrm{CO}_{2}$ mesocosms (P5 and P6). During the experiment, mean $p \mathrm{CO}_{2}$ levels were $\mathrm{C} 1: 429, \mathrm{C} 2:$ 427, C3: 429, P1: 508, P2: 586, P3: 660, P4: 747, P5: 828, P6: $990 \mu \mathrm{atm}$. [Chla] did not show any strong temporal trend, although levels slightly increased on day 10 to maximal concentrations of $0.09 \pm 0.003 \mu \mathrm{g} \mathrm{L}^{-1}$ on day 14 (Fig. 1). With regard to the heterotrophic prokaryotes, the initial average abundance (day 0 ) in all mesocosms was $5.0 \pm 0.3 \times 10^{5}$ cell $\mathrm{mL}^{-1}$. Their density remained relatively constant during the experiment, and ranged from $4.0 \times 10^{5}$ to $6.1 \times 10^{5}$ cell $\mathrm{mL}^{-1}$. The evolution of $\left[\mathrm{PO}_{4}{ }^{3-}\right]$, $\left[\mathrm{NO}_{\mathrm{x}}\right],[\mathrm{DOP}]_{\mathrm{UV}}$ and $[\mathrm{DON}]_{\mathrm{UV}}$ in $\mathrm{BC}$ in all mesocosms and outside is shown in Figure 2. After an initial decrease in $\left[\mathrm{PO}_{4}{ }^{3-}\right]$ inside and outside mesocosms between day 0 and day 1 , $\left[\mathrm{PO}_{4}{ }^{3-}\right]$ remained low and ranged from 3 to $12 \mathrm{nM}$ inside all mesocosms, and from 7 to $13 \mathrm{nM}$ outside until day 20. Regarding DOP, a decrease was also observed between day 0 and day 1 outside mesocosms and in control mesocosms (no data available for perturbed mesocosms at day 0 except for P2). From day 1 to day 13, [DOP] $]_{U V}$ varied between 5 and $20 \mathrm{nM}$ with no significant trend, except for P1 where an increase from 8 to $16 \mathrm{nM}$ (linear regression: $\mathrm{r}^{2}=$ $\left.0.89, \mathrm{n}=5, \mathrm{p}_{\text {value }}=0.02\right)$ was observed.

$\left[\mathrm{NO}_{\mathrm{x}}\right]$ increased from $47 \pm 14 \mathrm{nM}$ to $97 \pm 22 \mathrm{nM}$ in all mesocosms between day 0 and day 1 , followed by a decrease in both inside and outside mesocosms until day 8 (linear 
regression: $\left.\mathrm{r}^{2}=0.90, \mathrm{n}=8, \mathrm{p}_{\text {value }}<0.01\right)$. Then $\left[\mathrm{NO}_{\mathrm{x}}\right]$ remained very low $(8 \pm 6 \mathrm{nM})$ until day 13 (except for P2 (28 $\pm 9 \mathrm{nM})$, and a peak (52 nM) observed for P1). While a gradual increase in $\left[\mathrm{NO}_{\mathrm{x}}\right]$ occurred for $\mathrm{C} 2$ and $\mathrm{P} 6$ from day 16 until the end of the experiment, two peaks were observed on day 16 in P1 and P4 (105 and 124 nM respectively), and a strong increase was observed on day 17 for $\mathrm{C} 1, \mathrm{C} 3, \mathrm{P} 2, \mathrm{P} 3$ and P5. At the end of the experiment, $\left[\mathrm{NO}_{\mathrm{x}}\right]$ averaged $60 \pm 14 \mathrm{nM}$ in all mesocosms. After a high variability of [DON $]_{\mathrm{UV}}$ between mesocosms on day 0 , the average $[\mathrm{DON}]_{\mathrm{UV}}$, inside all mesocosms, varied around $4.8 \pm 0.3 \mu \mathrm{M}$ over the course of experiment. A slight decrease between day 1 and day 13 could be observed in all mesocosms (linear regression: $\mathrm{r}^{2}=0.83, \mathrm{n}=6, \mathrm{p}_{\text {value }}=0.01$ ).

\subsection{Environmental and experimental conditions during the winter experiment in the}

\section{Bay of Villefranche}

In $\mathrm{BV}$, drops in $p \mathrm{CO}_{2}$ levels were more important than in $\mathrm{BC}$ due to strong winds with mesocosms $\mathrm{P} 1$ to $\mathrm{P} 4$ showing very similar levels by the end of the experiment. Mean $p \mathrm{CO}_{2}$ levels were C1: 357, C2: 356, C3: 352, P1: 456, P2: 486, P3: 544, P4: 545, P5: 719, P6: 941

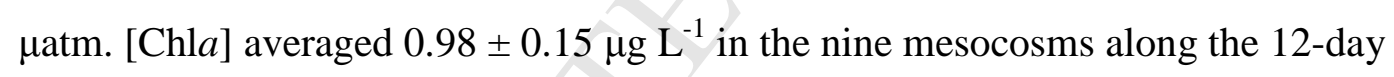
experiment. Chlorophyll $a$ remained slightly above levels in the surrounding waters for the entire experimental period, except for the last day (day 12) when concentrations increased abruptly outside the mesocosms. As one can see in Figure 1, [Chla] increased during the acidification phase, consuming a large proportion of available nutrients (see below), notably $\mathrm{NO}_{\mathrm{x}}$, before the start of the experimental phase (day 0). In all mesocosms, after this initial peak, $[\mathrm{Chl} a]$ gradually decreased until the end of the experiment. While the abundance of the heterotrophic prokaryotes outside the mesocosms remained constant over the experiment $(6.3$ $\pm 0.3 \times 10^{5}$ cell $\left.\mathrm{mL}^{-1}\right)$, it increased from day 2 to day 12 to reach $1.1 \pm 0.1 \times 10^{6}$ cell $\mathrm{mL}^{-1}$ 
inside all mesocosms. The initial average density of heterotrophic prokaryotes (day 0) was 7.3 $\pm 0.4 \times 10^{5}$ cell $\mathrm{mL}^{-1}$

$\left[\mathrm{PO}_{4}{ }^{3-}\right],\left[\mathrm{NO}_{\mathrm{x}}\right],[\mathrm{DOP}]_{\mathrm{Uv}},[\mathrm{DON}]_{\mathrm{Uv}}$ and DFe evolution in $\mathrm{BV}$ in all mesocosms and outside are shown in Figure 3. During the acidification phase, the increase in [Chla] outside and inside mesocosms was concomitant with the decrease in $\left[\mathrm{PO}_{4}{ }^{3-}\right.$ ( from $15 \pm 2$ to $10 \pm 2$ $\mathrm{nM})$ and $\left[\mathrm{NO}_{\mathrm{x}}\right]$. At day 0 , while $\left[\mathrm{NO}_{\mathrm{x}}\right]$ outside mesocosms remained high $(\sim 1 \mu \mathrm{M})$, all mesocosms were depleted in $\mathrm{NO}_{\mathrm{x}}$ with an average concentration of $129 \pm 30 \mathrm{nM}$.

No strong variations for $\left[\mathrm{PO}_{4}{ }^{3-}\right]$ were observed in the mesocosms over the course of the BV experiment (global average: $9 \pm 1 \mathrm{nM}$ ). $\left[\mathrm{PO}_{4}{ }^{3-}\right]$ was generally higher outside than inside mesocosms and a peak of $23 \mathrm{nM}$ was reached on day 6 followed by a decrease until the end of the experiment with similar inside and outside concentrations (12 nM at day 12). For the strongest perturbations (P4, P5 and P6), [DOP $]_{\mathrm{UV}}$ dropped between day 0 and day 1 , while $[\mathrm{DOP}]_{\mathrm{UV}}$ outside and in P2, P3 and control mesocosms tended to increase. [DOP $]_{\mathrm{UV}}$ then remained stable $(\sim 44 \pm 6 \mathrm{nM})$ in all mesocoms and outside until the end of the experiment.

Over the course of the BV experiment, $\left[\mathrm{NO}_{\mathrm{x}}\right]$ was much higher outside (range 889$1618 \mathrm{nM}$ ) than inside mesocosms (range 40-682 nM). Inside all mesocosms, $\left[\mathrm{NO}_{\mathrm{x}}\right]$ was stable until day 3 with an average concentration of $121 \pm 50 \mathrm{nM}$. A general increase in $\left[\mathrm{NO}_{\mathrm{x}}\right]$ occurred between day 3 and day 9 (linear regression: $\mathrm{r}^{2}=0.95, \mathrm{n}=6, \mathrm{p}_{\text {value }}<0.001$ ) with the largest rise observed in $\mathrm{P} 4, \mathrm{P} 2$ and $\mathrm{C} 2 .\left[\mathrm{NO}_{\mathrm{x}}\right]$ in those mesocosms was the highest measured during the BV experiment (Fig. 4). The lowest $\left[\mathrm{NO}_{\mathrm{x}}\right]$ was measured in $\mathrm{P} 1$ and the standard deviation was the lowest in $\mathrm{P} 6$ indicating that $\left[\mathrm{NO}_{\mathrm{x}}\right]$ in that mesocosm was more stable than elsewhere (Fig. 4).

With respect to DON, concentrations were around 3.5 $\pm 0.7 \mu \mathrm{M}$ inside and outside mesocosms and no clear trend could be observed, except for $\mathrm{C} 1$ and outside mesocosms 
where $[\mathrm{DON}]_{\mathrm{Uv}}$ increased after day 1 until day 10 (linear regression $\mathrm{C} 1: \mathrm{r}^{2}=0.86, \mathrm{n}=6, \mathrm{p}_{\mathrm{value}}$ $=0.02$; linear regression OUT: $\left.\mathrm{r}^{2}=0.82, \mathrm{n}=6, \mathrm{p}_{\text {value }}=0.03\right)$.

In addition to $\mathrm{NO}_{\mathrm{x}}, \mathrm{PO}_{4}{ }^{3-}, \mathrm{DON}$ and DOP, $[\mathrm{DFe}]$ data were documented during the experiment in BV. [DFe] were similar outside and inside mesocosms $(2.3 \pm 0.8$ vs. $2.5 \pm 1.2$ $\mathrm{nM}$, respectively). No clear trend was observed over the course of the experiment, although [DFe] slightly increased between day 3 and day 7 in all mesocosms.

\subsection{Nutrient dynamics vs. $p \mathrm{CO}_{2}$}

Box-plots of inorganic and organic nutrient concentrations during both experiments are shown in Figure 4, and relative MD (see section 2.4) of each perturbed mesocosm during the entire experiments was plotted against delta $p \mathrm{CO}_{2}$ for each perturbed mesocosm at each time-point, in Figure 5. During both experiments, $\left[\mathrm{PO}_{4}{ }^{3-}\right]$ dynamics were not significantly related to $p \mathrm{CO}_{2}$ levels. In addition, there was no significant relationship between $p \mathrm{CO}_{2}$ and relative $\mathrm{MD}$ for $\mathrm{PO}_{4}{ }^{3-}$ (Fig. 5; $\left.\mathrm{BC}: \mathrm{p}_{\text {value }}=0.06 ; \mathrm{BV}: \mathrm{p}_{\text {value }}=0.69\right)$. The same holds true for $[D O P]_{U V}\left(\right.$ Fig. $\left.5 ; B C: p_{\text {value }}=0.97 ; B V: p_{\text {value }}=0.33\right)$ and $[D O N]_{U v}$ in BC (Fig. 5; BC: $p_{\text {value }}=$ 0.35). In BV, despite the significant relationship between relative MD for [DON $]_{\mathrm{UV}}$ and delta $p \mathrm{CO}_{2}$ ( $\mathrm{p}_{\text {value }}$ of 0.03 ), this relationship appears weak considering the large observed deviation between the 3 controls (Figs. 4 and 5). In BC, $p \mathrm{CO}_{2}$ had no impact on $\left[\mathrm{NO}_{\mathrm{x}}\right]\left(\right.$ Fig. $5 ; \mathrm{p}_{\text {value }}=$ 0.31). In BV, although box-plots for $\left[\mathrm{NO}_{\mathrm{x}}\right]$ indicate a difference between controls, $\mathrm{P} 2$ and $\mathrm{P} 4$ on one side and P1, P3, P5 and P6 on the other side (Fig. 4), no significant effect of $p \mathrm{CO}_{2}$ gradient on $\mathrm{NO}_{\mathrm{x}}$ dynamics was observed (Fig. 5; $\mathrm{p}_{\text {value }}=0.36$ ). Despite the fact that [DFe] was generally lower in $\mathrm{CO}_{2}$-enriched mesocosms compared to controls (Fig. 4), the $p \mathrm{CO}_{2}$ gradient did not significantly affect the evolution of [DFe] when considering the full duration of the experiment (Fig. 5; BV: p palue $=0.91)$. 


\section{Discussion}

\subsection{Representativeness of the environmental settings}

The mesocosm experiments presented here focused on the impact of ocean acidification on plankton communities and are the first of such experiments to have been conducted in a low nutrient, low chlorophyll system. Our experimental protocol allowed for quantification of both inorganic and organic nutrient concentrations at nanomolar levels, and therefore allowed us to assess, in detail, temporal nutrient variability and contribution to the functioning of the community. Furthermore, this study provided the opportunity to compare nutrient levels measured at the two sites, with data compiled from the literature and obtained using both conventional (micromolar level) and nanomolar techniques (see Table 3). Finally, this compilation allowed us to put our results in a broader context of seasonal and spatial variability of nutrient levels in the Mediterranean Sea.

In the Bay of Calvi, the low initial in situ $\left[\mathrm{NO}_{\mathrm{x}}\right](50 \mathrm{nM})$ was in agreement with $\left[\mathrm{NO}_{\mathrm{x}}\right]$ $<30 \mathrm{nM}$ measured during a mesocosm experiment conducted in summer 2008 and 2010 in coastal waters of Corsica (Ridame et al., 2014). The low initial in situ $\left[\mathrm{PO}_{4}{ }^{3-}\right](35 \mathrm{nM})$ was consistent with data reported in previous studies conducted in the same season (Table 3; 5-20 $\mathrm{nM}$ in surface waters). These nitrate and phosphate depleted conditions, observed at the start of this experiment, are representative of summer oligotrophic conditions in the Mediterranean Sea.

In the Bay of Villefranche, the initial in situ $\left[\mathrm{NO}_{\mathrm{x}}\right](1.17 \mu \mathrm{M})$ was very close to the concentration $(1.25 \mu \mathrm{M})$ measured during the same week at a sampling site located at the entrance of the Bay (Service d'Observation en Milieu LITtoral; http://somlit.epoc.ubordeaux 1.fr/fr/ $)$. The same range $\left[\mathrm{NO}_{\mathrm{x}}=0.7-2.3 \mu \mathrm{M}\right]$ was also found at that site in surface waters in February 2012 (Thyssen et al., 2014). $\left[\mathrm{PO}_{4}{ }^{3-}\right]$ can be variable in winter in surface 
waters: $\sim 10 \mathrm{nM}$ in this study (but $\sim 50 \mathrm{nM}$ from SOMLIT, close to the detection limit using the conventional analytical method), from 25 to $92 \mathrm{nM}$ using a conventional analytical method (Thyssen et al., 2014) and 7 nM using nanomolar techniques (Louis et al., 2015). Those concentrations were low compared to the ones measured at the open ocean DYFAMED site ( $\left.43^{\circ} 25^{\prime} \mathrm{N}, 7^{\circ} 52^{\prime} \mathrm{E}\right)$ : $200-300 \mathrm{nM}$ during the winter-mixing period (January-February) followed by a decrease from 200 to $30 \mathrm{nM}$ during the winter-spring transition (Pulido-Villena et al., 2010). While a $\mathrm{NO}_{\mathrm{x}}$-replete system outside mesocosms was in agreement with conditions usually reported for the Mediterranean Sea in winter, it must be stressed that this was no longer the case at the start of the experiment inside all mesocosms. Instead, a rapid $\mathrm{NO}_{\mathrm{x}}$ uptake by phytoplankton during the acidification phase (4 days before day 0; Gazeau et al., submitted, this issue-a) was concomitant with the increase in biomass in all mesocosms (Figs. 1 and 3). This led to a sharp drop in [NOx] from 0.96 to $0.13 \mu \mathrm{M}$. Although $\left[\mathrm{NO}_{\mathrm{x}}\right]$ outside mesocosms also slightly declined (from 1.6 to $1.2 \mu \mathrm{M}$ ) during that acidification period, $\left[\mathrm{NO}_{\mathrm{x}}\right]$ was maintained at a higher level due to a winter-mixing situation (the vertical profile of temperature from SOMLIT indicated a homogeneous water column over $200 \mathrm{~m}$ ) and/or due to external input via atmospheric wet depositions (Migon, pers. comm.).

Therefore, the conditions encountered at the start of the experimental phase were not fully representative of winter conditions for that area.

The stoichiometric nutrient balance $\left[\mathrm{NO}_{\mathrm{x}}\right] /\left[\mathrm{PO}_{4}{ }^{3-}\right]$ can be used to depict the $\mathrm{P}$ or/and N (co)-limitation(s) for phytoplankton carbon fixation. In the Mediterranean Sea, below the mixed layer, $\left[\mathrm{NO}_{\mathrm{x}}\right] /\left[\mathrm{PO}_{4}{ }^{3-}\right]$ is close to 22 (e.g. Mc Gill, 1965; Krom et al., 1991; Pujo-Pay et al., 2011) and higher than the Redfield ratio (N/ P = 16). In deep waters, estimates are more robust as ratios are calculated based on $\left[\mathrm{PO}_{4}{ }^{3-}\right]$ and $\left[\mathrm{NO}_{\mathrm{x}}\right]$ well above the analytical detection limit (DL) of conventional analytical method (DL: $\left[\mathrm{PO}_{4}{ }^{3-}\right] \leq 20-50 \mathrm{nM}$ and $\left.\left[\mathrm{NO}_{\mathrm{x}}\right] \leq 20 \mathrm{nM}\right)$. 
In surface waters, reported ratios are much more variable: from 6 to 68 in the $0-150 \mathrm{~m}$ layer (Table 3). This reflects the difficulty to accurately measure nutrients with conventional methods in severely nutrient depleted waters, with concentrations often below DL during the stratification period (Pasqueron de Fommervault et al., 2015). Estimates of surface water ratios are thus questionable in terms of quality. In surface waters of the Bay of Calvi, using nanomolar techniques, we found an initial in situ $\left[\mathrm{NO}_{\mathrm{x}}\right] /\left[\mathrm{PO}_{4}{ }^{3-}\right]$ of 1.7 (Table 3), well below the Redfield ratio. Both low ratio and low nutrient concentrations suggest that this system experienced $\mathrm{N}$ and $\mathrm{P}$ co-limitation in summer, similarly to what was shown by Tanaka et al. (2011) in Svalbard. In winter in the Bay of Villefranche, initial in situ $\left[\mathrm{NO}_{\mathrm{x}}\right] /\left[\mathrm{PO}_{4}{ }^{3-}\right]$ was 177 due to high $\left[\mathrm{NO}_{\mathrm{x}}\right]$ and low $\left[\mathrm{PO}_{4}{ }^{3-}\right]$ at the start of the experiment. As mentioned above, $\mathrm{NO}_{\mathrm{x}}$ uptake occurred during the acidification phase, causing $\left[\mathrm{NO}_{\mathrm{x}}\right]$ to decrease to $129 \pm 30 \mathrm{nM}$ and leading to an average $\left[\mathrm{NO}_{\mathrm{x}}\right] /\left[\mathrm{PO}_{4}{ }^{3-}\right]=13$ in all mesocosms. These conditions suggest a potential $\mathrm{N}$ and $\mathrm{P}$ co-limitation for the plankton community.

During both summer and winter experiments, the contribution of dissolved organic nutrients to the total dissolved phosphate and nitrogen pool was high. This is in agreement with previous studies in the Mediterranean Sea $([\mathrm{DON}] /[\mathrm{TDN}]=60-100 \%$ and $[\mathrm{DOP}] /$ $[\mathrm{TDP}]=30-100 \%$; Table 3 ). Considering that organic forms of nutrients follow the same dynamics as DOM, which are known to accumulate in surface waters in the Northwestern Mediterranean Sea during the stratification period (Copin-Montegut and Avril, 1993), [DON] and [DOP] should peak in summer. In contrast, in our study, initial in situ [DON $]_{\mathrm{UV}}$ and $[\mathrm{DOP}]_{\mathrm{UV}}$ were higher in winter than in summer. The large labile fraction of DOP $(60-80 \%$; Aminot and Kerouel, 2004; Lønborg and Alvarez-Salgado, 2012) and the oligotrophic nature of the Mediterranean Sea could explain a high turnover rate of DOP, thus preventing its accumulation in surface waters. Previous studies in the Sargasso Sea (Lomas et al., 2010), as 
well as in an oligotrophic subtropical gyre (Steinberg et al., 2001), showed that [DOP] peaked during the winter/spring bloom and declined slowly throughout the summer resulting in enhanced P-stress. This was concomitant with an increase in the alkaline phosphatase activity (APA). Similarly, in the present study, APA was higher in summer than in winter (Celussi et al., in press, this issue), possibly explaining lower [DOP] in summer than in winter. At the start of the experiment in the Bay of Villefranche, in situ $[\mathrm{DON}]_{\mathrm{UV}}$ and $[\mathrm{DOP}]_{\mathrm{UV}}$ were close to reported concentrations for the Mediterranean Sea in winter (Table 2; Raimbault et al., 1999; Santinelli et al., 2002). In the Bay of Calvi, in situ [DOP $]_{U v}$ was in the range (0.01 $0.10 \mu \mathrm{M}$ ) of reported data in summer in surface waters of the Mediterranean Sea (Table 3). With respect to in situ $[\mathrm{DON}]_{\mathrm{Uv}}$, the observed value of $2 \mu \mathrm{M}$ was lower than concentrations reported previously for the western basin in winter (from 4.5 to $5.5 \mu \mathrm{M}$; Raimbault et al., 1999; Table 3).

In the Bay of Villefranche, initial in situ [DFe] (1.2 nM; Table 1) was lower than values reported in the Bay of Villefranche at the same season by Bressac and Guieu (2013; $3.8 \mathrm{nM}$ at $5 \mathrm{~m}$ ) and, instead, more similar to winter offshore concentrations (DYFAMED site, $0.81 \pm 0.07 \mathrm{nM}$; Bonnet and Guieu, 2006). The annual [DFe] dynamics in surface waters in the Northwestern Mediterranean Sea are controlled by several factors such as atmospheric deposition, winter mixing, phytoplankton uptake, and particle scavenging. Over an annual time scale, [DFe] ranged from 0.2 to $1.2 \mathrm{nM}$ at DYFAMED site (Bonnet and Guieu, 2006). Minimal values were measured when $[\mathrm{Chl} a]$ was the highest, as a consequence of biological uptake and removal by the sinking particles. Under stratified conditions, atmospheric deposition results in an accumulation of [DFe] in surface waters that is isolated from deeper layers (Bonnet and Guieu, 2006; Guieu et al., 2010). Because atmospheric inputs, such as Saharan dust deposition, have high interannual variability (Guieu et al., 2014 and ref within), 
[DFe] concentrations in surface waters are likely also highly variable from one year to another. This could explain the different [DFe] observed in the Bay of Villefranche at similar season. At the start of the winter experiment in the Bay of Villefranche, [DFe] in surface waters was reflective of [DFe] found in the open western Mediterranean Sea in winter.

\subsection{Nutrient dynamics: Biological vs. Acidification effect}

During both experiments, results showed that none of the parameters investigated in this study were linearly related to $\mathrm{CO}_{2}$ enrichment (Fig. 5). These two experiments, conducted in waters depleted in $\mathrm{PO}_{4}{ }^{3-}$, showed low variations in $\mathrm{PO}_{4}{ }^{3-}$ over the experimental period and no significant differences in $\mathrm{PO}_{4}{ }^{3-}$ dynamics over the different $p \mathrm{CO}_{2}$ conditions. With respect to $\mathrm{NO}_{\mathrm{x}}$, concentrations followed the same temporal trend with no significant differences between control and perturbed mesocosms (Figs. 4 and 5). In the Bay of Villefranche, during the acidification phase, although targeted $p \mathrm{CO}_{2}$ conditions were not yet reached, a drop in $\mathrm{NO}_{\mathrm{x}}$ observed in all mesocosms suggested that $\mathrm{NO}_{\mathrm{x}}$ uptake by phytoplankton was not impacted by an increase in $p \mathrm{CO}_{2}$ in the perturbed mesocosms. During the summer and winter experiments, a trend in $\mathrm{DON}_{\mathrm{UV}}$ and $\mathrm{DOP}_{\mathrm{UV}}$ was now observed, and concentrations were not affected by acidification (Fig. 5). Although a decrease in $\mathrm{pH}$ would favor the solubility of

DFe (Breitbarth et al., 2010a), DFe concentrations did not increase with increasing $p \mathrm{CO}_{2}$ (Fig. 5). As such, it appears that both direct chemical and indirect biological processes (further discussed in this section) that controlled nutrient dynamics during these experiments were independent of $p \mathrm{CO}_{2}$ conditions.

Previous mesocosm experiments, similar to the ones presented here, focused on the effect of ocean acidification on plankton communities but were performed under nutrient replete conditions using artificial nutrient addition. For instance, in the framework of the Pelagic Ecosystem $\mathrm{CO}_{2}$ Enrichment (PeECE) project, three land-based mesocosm 
experiments were conducted in Bergen (Norway), in 2001, 2003 and 2005 (PeECE I, II and III, respectively). In 2001 and 2003, three treatments represented low (190 $\mu$ atm), present-day (370-410 $\mu \mathrm{atm})$ and high $(700 \mu \mathrm{atm}) p \mathrm{CO}_{2}$ conditions. In PeECE III, there was one presentday condition and two high $p \mathrm{CO}_{2}$ levels $(350,700$ and $1050 \mu \mathrm{atm})$. After nutrient addition, $\left[\mathrm{NO}_{\mathrm{x}}\right]_{\text {initial }}$ and $\left[\mathrm{PO}_{4}{ }^{3-}\right]_{\text {initial }}$ were 15 and $0.5 \mu \mathrm{M}$ respectively during PeECE I, 9 and $0.4 \mu \mathrm{M}$ respectively during PeECE II, and 16 and $0.8 \mu \mathrm{M}$ respectively during PeECE III. During all three experiments, and in agreement with our results, $\mathrm{NO}_{\mathrm{x}}$ and $\mathrm{PO}_{4}{ }^{3-}$ uptake were similar in all mesocosms, indicating that phytoplankton nutrient uptake was insensitive to changes in seawater pH (Engel et al., 2005 and 2008; Schulz et al., 2008; Bellerby et al., 2008). As similar increases in DOC, DON and DOP were observed in all PeECE mesocosms, this further suggests that acidification, as observed in our experiments, did not impact the production or consumption of dissolved organic nutrients. In contrast to the lack of $p \mathrm{CO}_{2}$ effects on inorganic and organic macronutrients, Breitbarth et al. (2010b) have shown, during the PeECE III experiment and in agreement with previous studies (e.g. Liu and Millero, 2002; Millero et al., 2009), that ocean acidification may lead to enhanced Fe-bioavailability due to (1) an increase in the organically complexed Fe (III) and (2) an increase in Fe(II) concentrations. This is not consistent with data acquired during our experiment in the Bay of Villefranche where $[\mathrm{DFe}]$ in high- $\mathrm{CO}_{2}$ mesocosms were not significantly higher than in low$\mathrm{CO}_{2}$ mesocosms.

More recently, a large off-shore mesocosm experiment has been conducted in the Arctic ocean (Svalbard) following a $p \mathrm{CO}_{2}$ gradient ranging from 185 to $1420 \mu \mathrm{atm}$. This study has shown that, before nutrient addition $\left(\left[\mathrm{NO}_{\mathrm{x}}\right]=0.1 \mu \mathrm{M}\right.$ and $\left.\left[\mathrm{PO}_{4}{ }^{3-}\right]=0.06-0.09 \mu \mathrm{M}\right)$, in agreement with our results, organic and inorganic nutrient dynamics were similar in all $p \mathrm{CO}_{2}$ treatments (Schulz et al., 2013). During the phytoplankton growth stimulated by nutrient addition (after day $13,\left[\mathrm{NO}_{\mathrm{x}}\right]_{\mathrm{d} 13}=5.5 \mu \mathrm{M}$ and $\left[\mathrm{PO}_{4}{ }^{3-}\right]_{\mathrm{d} 13}=0.4 \mu \mathrm{M}$ ), while the same 
dynamics in DON and DOP were observed in all mesocosms, inorganic nutrient uptake $\left(\mathrm{NO}_{\mathrm{x}}\right.$ and $\mathrm{PO}_{4}{ }^{3}$ ) was faster at higher $\mathrm{CO}_{2}$ levels indicating a shift in phytoplankton community composition (Schulz et al., 2013), a shift that was not observed during our experiments (Gazeau et al. submitted, this issue-b).

Among the very few bottle experiments focused on the effect of ocean acidification on planktonic communities under low nutrient conditions, results of Yoshimura et al. (2010; $\left[\mathrm{NO}_{\mathrm{x}}\right]_{\text {initial }}=0.05 \pm 0.02 \mu \mathrm{M}$ and $\left.\left[\mathrm{PO}_{4}{ }^{3-}\right]_{\text {initial }}=0.25 \pm 0.01 \mu \mathrm{M}\right)$ support our conclusion that under limiting conditions, nutrient dynamics are not dependent on $p \mathrm{CO}_{2}$ levels.

In our study, nutrient measurements were performed at nanomolar levels providing greater detail to assess temporal dynamics. As nutrients dynamics did not differ between $p \mathrm{CO}_{2}$ levels, the nine mesocosms can be considered as replicate measurements. As such, daily average nutrient concentrations were calculated (Figs. 6, 7 and 8) providing insight to the relationship between nutrient dynamics and major biological parameters (chlorophyll $a$, particulate organic carbon, organic matter) and processes (production and degradation, heterotrophic enzymatic activities, nitrification). Such stocks and fluxes, measured during the experiments, are presented and discussed in details in companion papers (Gazeau et al., submitted, this issue-b; Maugendre et al., in press, this issue-a; Celussi et al., in press, this issue).

As a brief summary of the companion papers, during the summer experiment in the Bay of Calvi, $\mathrm{CO}_{2}$ enrichment did not have any significant effect on primary production (Maugendre et al. in press, this issue-a), abundance and activity of heterotrophic prokaryotes (Celussi et al., in press, this issue), as well as Chla concentrations and phytoplankton community composition (Gazeau et al., submitted, this issue-b). The summer plankton community was mostly composed of small species such as haptophytes and cyanobacteria 
(Gazeau et al., submitted, this issue-b), dominated by mixotrophs or heterotrophs. While the carbon biomass of autotrophs was very low (from $0.009 \pm 0.003$ to $0.022 \pm 0.009 \mu \mathrm{mol} \mathrm{C} \mathrm{L}^{-1}$; based on compound specific ${ }^{13} \mathrm{C}$ incorporation; Maugendre et al., in press, this issue-b), mixotrophs represented the most productive group with an increasing biomass over the experimental period (from $0.05 \pm 0.01$ to $0.08 \pm 0.03 \mu \mathrm{mol} \mathrm{C} \mathrm{L} \mathrm{L}^{-1}$ ). The low biomass of autotrophs determined by Maugendre et al. (in press, this issue-b) was consistent with the low average [Chl $a$ ] measured in the Bay of Calvi (from 0.06 to $0.08 \mu \mathrm{g} \mathrm{L}^{-1}$; Fig. 6). Despite a low autotrophic production, $\left[\mathrm{NO}_{\mathrm{x}}\right]$ decreased by $50 \%$ throughout the experiment and $\left[\mathrm{PO}_{4}{ }^{3-}\right]$ decreased during the first day and then slightly decreased until day 7 (Fig. 6). In such a nutrient-depleted system, haptophytes, considered as mixotrophic, are known to be good competitors for low nutrient resources (Sanders, 1991). The ratio between uptake rates of $\mathrm{NO}_{\mathrm{x}}$ (12.8 nmol N L $\left.{ }^{-1} \mathrm{~d}^{-1}\right)$ and $\mathrm{PO}_{4}{ }^{3-}\left(0.5 \mathrm{nmol} \mathrm{P} \mathrm{L}{ }^{-1} \mathrm{~d}^{-1}\right)$, determined from the slope of $\mathrm{NO}_{\mathrm{x}}$ and $\mathrm{PO}_{4}{ }^{3-}$ decreases between day 1 and day 7 , was around 25 . This is close to the typical $\left[\mathrm{NO}_{\mathrm{x}}\right] /$ $\left[\mathrm{PO}_{4}{ }^{3-}\right]$ in Mediterranean waters below the mixed layer $(\sim 22)$. Despite a slight decrease in $[\mathrm{DON}]_{\mathrm{Uv}}$, an uptake of DOP was not observed (except between day 0 and day 1$)$. This was unexpected since the gradual increase of the alkaline phosphatase activity (APA) observed until day 12 (on average $169 \mathrm{nM} \mathrm{h}^{-1}$; Celussi et al., in press, this issue) should be concomitant with a decrease in [DOP] (i.e., Ruttenburg and Dyhrman, 2002; Mahaffey et al., 2014; Fig. 7). It could be due to either the low [DOP $]_{\mathrm{UV}}$ during this experiment and/or a rapid turnover of DOP (Benitez-Nelson and Buesseler, 1999). Towards the end of the experiment, $\left[\mathrm{NO}_{\mathrm{x}}\right]$ raised while $\left[\mathrm{PO}_{4}{ }^{3-}\right]$ remained stable (Fig. 6). Excluding the external inputs in the mesocosms by UV-transparent roofs covering them, the release of $\mathrm{NO}_{\mathrm{x}}$ would result from bacterial remineralization.

In the Bay of Villefranche, as already mentioned, a rapid nutrient uptake by phytoplankton was observed during the acidification phase, concomitant with the increase in 
biomass (Fig. 6). After this $[\mathrm{Chl} a]$ increase (and $\left[\mathrm{NO}_{\mathrm{x}}\right]$ drop) in all mesocosms, the biomass of the autotrophic community decreased (from 1.1 to $0.9 \mu \mathrm{g} \mathrm{L}^{-1}$ ) while the abundance of heterotrophic prokaryotes increased in all mesocosms (from $7.3 \times 10^{5}$ cell $\mathrm{mL}^{-1}$ to $1.1 \times 10^{6}$ cell $\mathrm{mL}^{-1}$; Fig. 6). From day 3 , an increase in $\left[\mathrm{NO}_{\mathrm{x}}\right]$ occurred in all mesocosms that was likely linked to enhanced heterotrophic prokaryotes activity (Fig. 6). It is possible that the increase in $\left[\mathrm{NO}_{\mathrm{x}}\right]$ of $\sim 18 \mathrm{nmol} \mathrm{N} \mathrm{L} \mathrm{d}^{-1}$ was induced by nitrification activity estimated to be $\sim 19 \mathrm{nmol}$ $\mathrm{N} \mathrm{L}^{-1} \mathrm{~d}^{-1}$ (Al-Moosawi, pers. comm.) although no negative correlation between $\left[\mathrm{NH}_{4}^{+}\right]$and $\left[\mathrm{NO}_{\mathrm{x}}\right]$ could be observed (Fig. $8 \mathrm{~b}$ ). Nitrification could have been preceded by ammonification of the DON pool produced from the degradation of particulate organic matter by heterotrophic prokaryotes. This could explain the negative correlation between particulate organic carbon concentrations ([POC]) and $\left[\mathrm{NO}_{\mathrm{x}}\right]($ Fig. 8c), while $[\mathrm{DON}]$ remained stable (Fig. 8a; sampling and analytical protocols for POC are described in Gazeau et al., submitted, this issue-b). The decrease in POC could also be due to the phytoplankton cell lysis under experimental stress (e.g. water column trapped in mesocosm). The large amount of released nutrient-rich organic matter resulted in an increase in bacterial abundance and heterotrophic activity. Ultimately, regenerated inorganic nutrients such as $\mathrm{NH}_{4}{ }^{+}$and $\mathrm{NO}_{\mathrm{x}}$ by nitrification were produced (Al-Moosawi, pers. comm.). While the heterotrophic activity based on the regenerated production was usually higher in summer, the increase in phytoplankton biomass (mostly composed of small species such as cryptophyceae and haptophyceae; Gazeau et al. submitted, this issue-b) at the start of experiment in the Bay of Villefranche allowed an increase in the abundance and activity of heterotrophic prokaryotes (see Celussi et al., in press, this issue, for further details).

Finally, in the Bay of Villefranche, in relation to the increase in heterotrophic activity and nitrification, [DFe] increased significantly ( $\left.\mathrm{p}_{\text {value }}<0.001\right)$ from day 3 to day 7 (Fig. 9a). This could be the result of either an enhancement of Fe solubility by organic ligands exuded 
by phytoplankton or the release of DFe in seawater after cell death (Witter et al., 2000) while $[\mathrm{Chl} a]$ decreased. A negative relationship between $[\mathrm{DFe}]$ and $[\mathrm{Chl} a]\left(\mathrm{p}_{\text {value }}=0.001\right)$ was indeed observed between day 3 and day 7 (Fig. 9b). Although [Chla] continued to decline until day 11, [DFe] did not increase after day 7. Finally, other biotic and abiotic processes such as scavenging and/or aggregation (Johnson et al., 1997), that were not explicitly studied here, could have explained this decrease in [DFe] observed at the end of the experiment. 


\section{Conclusion}

These first ocean acidification mesocosm experiments conducted in coastal LNLC areas allowed for investigation of the effect of ocean acidification on nutrient dynamics using nanomolar techniques. While the summer experiment was fully representative of oligotrophic summer conditions in the Mediterranean Sea, the winter experiment failed to reproduce the mesotrophic conditions typical of the winter time. Instead post-bloom conditions were also encountered, with high concentrations of phytoplankton exudates and low nutrient concentrations.

Based on these two experiments, ocean acidification did not affect the dynamics of nutrients both under inorganic and organic forms: (1) the concentration of dissolved organic nutrients remained stable regardless of $p \mathrm{CO}_{2}$ conditions, (2) the expected increase in iron solubility at high $p \mathrm{CO}_{2}$ was not observed and (3) the dynamics of $\mathrm{NO}_{\mathrm{x}}$ and $\mathrm{PO}_{4}{ }^{3-}$ were controlled by the biological processes independently of $p \mathrm{CO}_{2}$ conditions.

Although the use of nanomolar techniques during these experiments facilitated documentation of nutrient dynamics with great precision, the direct measurement of the turnover times of $\mathrm{P}$ and $\mathrm{N}$ would provide a better view on these dynamics resulting from biological uptake. Such measurement would improve the assessment of ocean acidification impacts on plankton nutrient uptake, particularly in summer, when the turnover time of $\mathrm{P}$ is very low (1-2 h; Moutin et al., 2002b). As such, we recommend the measurement of nutrient turnover rates over nanomolar measurements in future mesocosm studies conducted in oligotrophic areas.

This absence of $p \mathrm{CO}_{2}$ effects on the bioavailability of nutrients in low nutrient and low chlorophyll waters suggests that there will be no direct positive or negative feedback by the biological pump in response to the rise in atmospheric $\mathrm{CO}_{2}$. However, other changes 
projected with climate change, such as the increase in water column stratification, seawater temperature, extreme events occurrence, could induce shifts in the nutrient stoichiometry with important impacts on the diversity of the natural plankton assemblage. The response of marine ecosystems to on-going environmental changes in oligotrophic areas should be tackled using multi-stressor approaches (such as combining ocean acidification, warming and atmospheric deposition) in future investigations. 


\section{Acknowledgements}

This work was funded by the EC FP7 project 'Mediterranean Sea Acidification in a changing climate' (MedSeA; grant agreement 265103), the project European Free Ocean Carbon Enrichment (eFOCE; BNP-Paribas foundation), the MISTRALS-MERMEX program (Institut des Sciences de l'Univers, INSU), the Corsican local authorities and the RhoneMediterranean and Corsica Water Agency (http://www.eaurmc.fr). It is a contribution to the Surface Ocean - Lower Atmosphere Study (SOLAS), the Integrated Marine Biogeochemistry and Ecosystem Research (IMBER) and the LOICZ projects. The STARESO marine station in Corsica is gratefully acknowledged for its assistance and boat support carried out within the framework of the STARECAPMED project funded by the RhoneMediterranean and Corsica Water Agency. A grant provided by the University of Paris 6 supported J.L. The staff of the Observatoire Océanologique de Villefranche is gratefully acknowledged for their assistance and boat support, colleagues of the Laboratoire d'Océanographie de Villefranche for providing laboratory space. J.-M. Grisoni, A. Sallon, G. Obolensky, S. Alliouane, B. Hesse, D. Luquet, D. Robin, P. Mahacek and E. Cox are acknowledged for assistance with diving operations. L. Kapsenberg is acknowledged for a careful check of English grammar. 


\section{References}

Aït-Ameur, N., and C. Goyet. 2006. « Distribution and transport of natural and anthropogenic $\mathrm{CO}_{2}$ in the Gulf of Cádiz ». Deep Sea Research Part II: Topical Studies in Oceanography, The Gulf of Cadiz oceanography: a multidisciplinary view, 53 (1113): 1329-1343. doi:10.1016/j.dsr2.2006.04.003.

Aminot, A., and R. Kérouel. 2004. «Dissolved organic carbon, nitrogen and phosphorus in the N-E Atlantic and the N-W Mediterranean with particular reference to nonrefractory fractions and degradation ». Deep Sea Research Part I: Oceanographic Research Papers 51 (12): 1975-1999. doi:10.1016/j.dsr.2004.07.016.

Armstrong, F. a. J., and S. Tibbitts. 1968. «Photochemical combustion of organic matter in sea water, for nitrogen, phosphorus and carbon determination ». Journal of the Marine Biological Association of the United Kingdom 48 (01): 143-152. doi:10.1017/S0025315400032483.

Bellerby, R. G. J., K. Schulz, U. Riebesell, C. Neill, G. Nondal, T. Johannessen, and K. R. Brown. 2008. « Marine ecosystem community carbon and nutrient uptake stoichiometry under varying ocean acidification during the PeECE III experiment ». Biogeosciences 5 (6): 1517-1527.

Beman, J. M., C.-E. Chow, A. L. King, Y. Feng, J. A. Fuhrman, A. Andersson, N. R. Bates, B. N. Popp, and D. A. Hutchins. 2011. « Global declines in oceanic nitrification rates as a consequence of ocean acidification ». Proceedings of the National Academy of Sciences 108 (1): 208-213. doi:10.1073/pnas.1011053108.

Benitez-Nelson, C., and K. Buesseler. 1997. «Variability of inorganic and organic 
phosphorus turnover rates in the coastal ocean ». J Org Chem 62: 2619-2621.

Bonnet, S., and C. Guieu. 2006. « Atmospheric forcing on the annual iron cycle in the Western Mediterranean Sea: a 1-year survey ». Journal of Geophysical Research 111 (C9). doi:10.1029/2005JC003213.

Breitbarth, E., E. P. Achterberg., M. V. Ardelan, A. R. Baker, E. Bucciarelli., F. Chever, and C. Hassler.. 2010a. «Iron biogeochemistry across marine systems-progress from the past decade ». Biogeosciences 7(3), 1075-1097.

Breitbarth, E., R. J. Bellerby, C. C. Neill, M. V. Ardelan, M.l Meyerhöfer, E. Zöllner, P. Croot, and U. Riebesell. 2010b. « Ocean acidification affects iron speciation during a coastal seawater mesocosm experiment ». Biogeosciences 7 (3): 1065-1073.

Bressac, M., and C. Guieu. 2013. «Post-depositional processes: what really happens to new atmospheric iron in the ocean's surface?». Global Biogeochemical Cycles 27 (3): 859870. doi:10.1002/gbc.20076.

Bronk, D. A., J. H. See, P. Bradley, and L. Killberg. 2007. «DON as a source of bioavailable nitrogen for phytoplankton ». Biogeosciences 4 (3): 283-296.

Bruland, K. W., R. P. Franks, G. A. Knauer, and J. H. Martin. 1979. « Sampling and analytical methods for the determination of copper, cadmium, zinc, and nickel at the nanogram per liter level in sea water ». Analytica Chimica Acta 105: 233-245.

Brussaard, C. P. D., G. J. Gast, F. C. Van Duyl, R. Riegman, and others. 1996. «Impact of phytoplankton bloom magnitude on a pelagic microbial food web ». Marine ecology progress series. Oldendorf 14 (1): 211-221.

Celussi, M., Dellisanti, W., Del Negro, P., Franzo, A., Gazeau, F., Giannakourou, A., 
Konstantinopoulou, A., Pitta, P., Tsiola, A., in press, this issue. « Ocean acidification effect on microbial metabolism in two different locations in the Mediterranean Sea ». Estuarine, Coastal and Shelf Science.

Ciais P, C. Sabine, G. Bala, L. Bopp, V. Brovkin, J. Canadell, A. Chhabra, R. DeFries, J. Galloway, M. Heimann, C. Jones, C. Le Quéré, R. B. Myneni, S. Piao, P. Thornton. 2013. «Carbon and Other Biogeochemical Cycles. » In: Climate Change 2013: The Physical Science Basis Contribution of Working Group I to the Fifth Assessment Report of the Intergovernmental Panel on Climate Change [Stocker TF, Qin D, Plattner G-K, Tignor M, Allen SK, Boschung J, Nauels A, Xia Y, Bex V, Midgley PM (eds)]. Cambridge University Press, Cambridge, United Kingdom and New York, NY, USA.

CIESM, 2008. «Biogeochemical impacts of ocean acidification- emphasis on carbonate production and dissolution ». In CIESM Workshop Monographs. CIESM, Monaco. http://ciesm.org/online/monographs/36/WM_36_51_54.pdf.

Collins, M., R. Knutti, J. Arblaster, J.-L. Dufresne, T. Fichefet, P. Friedlingstein, X. Gao, W.J. Gutowski, T. Johns, G. Krinner, M. Shongwe, C. Tebaldi, A.J. Weaver and M. Wehner. 2013. «Long-term Climate Change: Projections, Commitments and Irreversibility. » In: Climate Change 2013: The Physical Science Basis. Contribution of Working Group I to the Fifth Assessment Report of the Intergovernmental Panel on Climate Change [Stocker, T.F., D. Qin, G.-K. Plattner, M. Tignor, S.K. Allen, J. Boschung, A. Nauels, Y. Xia, V. Bex and P.M. Midgley (eds.)]. Cambridge University Press, Cambridge, United Kingdom and New York, NY, USA.

Copin-Montégut, G., and B. Avril. 1993. «Vertical distribution and temporal variation of dissolved organic carbon in the North-Western Mediterranean Sea ». Deep Sea 
Research Part I: Oceanographic Research Papers 40 (10): 1963-1972.

doi:10.1016/0967-0637(93)90041-Z.

Coste, B., P. Le Corre, and H. J. Minas. 1988. « Re-evaluation of the nutrient exchanges in the strait of gibraltar ». Deep Sea Research Part A. Oceanographic Research Papers 35 (5): 767-775. doi:10.1016/0198-0149(88)90029-5.

De Rijck, G., and E. Schrevens. 1998. « Cationic speciation in nutrient solutions as a function of $\mathrm{pH} »$. Journal of plant nutrition 21 (5): 861-870.

Diaz, F., P.Raimbault, B. Boudjellal, N.Garcia, and T. Moutin. 2001. « Early spring phosphorus limitation of primary productivity in a NW Mediterranean coastal zone (Gulf of Lions) ». Marine Ecology Progress Series 211: 51-62.

Dickson, A. G., C. L. Sabine, J. R. Christian. 2007. « Guide to best practices for ocean $\mathrm{CO}_{2}$ measurements ». Report. North Pacific Marine Science Organization.

Doney, S. C., V. J. Fabry, R. A. Feely, and J. A. Kleypas. 2009. « Ocean acidification: the other $\mathrm{CO}_{2}$ problem ». Annual Review of Marine Science 1 (1): 169-192. doi:10.1146/annurev.marine.010908.163834.

D’Ortenzio, F., D. Antoine, and S. Marullo. 2008. « Satellite-driven modeling of the upper ocean mixed layer and air-sea $\mathrm{CO}_{2}$ flux in the Mediterranean Sea ». Deep Sea Research Part I: Oceanographic Research Papers 55 (4): 405-434. doi:10.1016/j.dsr.2007.12.008.

Dyhrman, S. T., and K. C. Ruttenberg. 2006. « Presence and regulation of alkaline phosphatase activity in eukaryotic phytoplankton from the coastal ocean: Implications for dissolved organic phosphorus remineralization ». Limnology and Oceanography 
51 (3): 1381-1390.

Engel, A, B Delille, S Jacquet, U Riebesell, E Rochelle-Newall, A Terbrüggen, and I Zondervan. 2004. «Transparent exopolymer particles and dissolved organic carbon production by Emiliania huxleyi exposed to different $\mathrm{CO}_{2}$ concentrations: a mesocosm experiment ». Aquatic Microbial Ecology 34: 93-104. doi:10.3354/ame034093.

Engel, A. 2002. « Direct relationship between $\mathrm{CO}_{2}$ uptake and transparent exopolymer particles production in natural phytoplankton ». Journal of Plankton Research 24 (1): 49-53. doi:10.1093/plankt/24.1.49.

Engel, A., I. Zondervan, K. Aerts, L. Beaufort, A. Benthien, L. Chou, B. Delille, et al. 2005. « Testing the direct effect of $\mathrm{CO}_{2}$ concentration on a bloom of the coccolithophorid Emiliania huxleyi in mesocosm experiments ». Limnology and Oceanography 50 (2): 493-507.

Engel, A., C. Borchard, J. Piontek, K. G. Schulz, U. Riebesell, and R. Bellerby. 2003. « $\mathrm{CO}_{2}$ increases ${ }^{14} \mathrm{C}$ primary production in an Arctic plankton community ». Biogeosciences 10 (3): 1291-1308. doi:10.5194/bg-10-1291-2013.

Gazeau, F., A. Sallon, L. Maugendre, J. Louis, W. Dellisanti, M. Gaubert, P. Lejeune, S. Gobert, S. Alliouane, V. Taillandier, F. Louis, G. Obolensky, J.-M. Grisoni and C. Guieu, submitted, this issue-a. « First mesocosm experiments to study the impacts of ocean acidification on plankton communities in the NW Mediterranean Sea (MedSeA project)». Estuarine, Coastal and Shelf Science.

Gazeau, F., A. Sallon, P. Pitta, M.-L. Pedrotti, S. Marro, and C. Guieu, C., submitted, this issue-b. «Effect of ocean acidification on the plankton community diversity and 
organic matter in the NW oligotrophic Mediterranean Sea: results from two mesocosm studies ». Estuarine, Coastal and Shelf Science.

Grossart, H.-P., M. Allgaier, U. Passow, and U. Riebesell. 2006. « Testing the effect of $\mathrm{CO}_{2}$ concentration on dynamics of marine heterotrophic bacterioplankton ». Limnology and oceanography 51 (1): 1-11.

Guieu, C., M. -D. Loÿe-Pilot, L. Benyahya, and A. Dufour. 2010. « Spatial variability of atmospheric fluxes of metals ( $\mathrm{Al}, \mathrm{Fe}, \mathrm{Cd}, \mathrm{Zn}$ and $\mathrm{Pb})$ and phosphorus over the whole Mediterranean from a one-year monitoring experiment: Biogeochemical implications ». Marine Chemistry, Aerosol chemistry and impacts on the ocean, 120 (1-4): 164-178. doi:10.1016/j.marchem.2009.02.004.

Guieu, C., F. Dulac, C. Ridame, and P. Pondaven. 2014. «Introduction to project DUNE, a DUst experiment in a low Nutrient, low chlorophyll Ecosystem ». Biogeosciences $11(2), 425-442$.

Hartmann, D. L., A. M. G. Klein Tank, M. Rusicucci, L. V. Alexander, B. Broenniman, Y. Charabi, F. J. Dentener, et al. 2013. «Observations: atmosphere and surface ». In Climate Change 2013: the physical science basis. Contribution of Working Group I to the Fifth Assessment Report of the Intergovernmental Panel on Climate Change, édité par T. F. Stocker, D. Qin, G.-K. Plattner, M. Tignor, S. K. Allen, J. Boschung, A. Nauels, Y. Xia, V. Bex, et P. M. Midgley, 159-254. Cambridge: Cambridge University

Hoffmann, L., E. Breitbarth, P. Boyd, and K. Hunter. 2012. «Influence of ocean warming and acidification on trace metal biogeochemistry ». Marine Ecology Progress Series 470 191-205. doi:10.3354/meps10082. 
Holland, H.D., W. H. Schlesinger, and K. K. Turekian. 2005. Biogeochemistry. Gulf Professional Publishing.

Hutchins, D. A., F.-X. Fu, Y. Zhang, M. E. Warner, Y. Feng, K. Portune, P. W. Bernhardt, and M. R. Mulholland. 2007. « $\mathrm{CO}_{2}$ control of Trichodesmium $\mathrm{N}_{2}$ Fixation, photosynthesis, growth rates, and elemental ratios: implications for past, present, and future ocean biogeochemistry ». Limnology and Oceanography 52 (4): 1293-1304. doi:10.4319/1o.2007.52.4.1293.

Hutchins, D., M. Mulholland, and F. Fu. 2009. « Nutrient cycles and marine microbes in a $\mathrm{CO}_{2}$-enriched ocean ». Oceanography 22 (4): 128-145. doi:10.5670/oceanog.2009.103.

Jackson, G. A., and P. M. Williams. 1985. «Importance of dissolved organic nitrogen and phosphorus to biological nutrient cycling ». Deep Sea Research Part A. Oceanographic Research Papers 32 (2): 223-235.

Johnson, K. S., R. M. Gordon, and K.H. Coale. 1997. «What controls dissolved iron concentrations in the world ocean?». Marine Chemistry 57 (3-4): 137-161. doi:10.1016/S0304-4203(97)00043-1.

Karl D.M., and K.M. Bjorkman. 2002. « Dymanics of DOP ». In DA Hansell, CA Carlson (eds.), Biogeochemistry of marine dissolved organic matter: 249-366

Krom, M. D., N. Kress, S. Brenner, and L. I. Gordon. 1991. «Phosphorus limitation of primary productivity in the Eastern Mediterranean Sea ». Limnology and Oceanography 36 (3): 424-432. doi:10.4319/1o.1991.36.3.0424.

Krom, M.D., E.M.S. Woodward, B. Herut, N. Kress, P. Carbo, R.F.C. Mantoura, G. Spyres, 
et al. 2005. « Nutrient cycling in the South East Levantine basin of the Eastern Mediterranean: results from a phosphorus starved system ». Deep Sea Research Part II: Topical Studies in Oceanography 52 (22-23): 2879-2896. doi:10.1016/j.dsr2.2005.08.009.

Lavigne, H., J. M. Epitalon and J. P. Gattuso. 2014. Seacarb: seawater carbonate chemistry with R. http://CRAN.R-project.org/package=seacarb (last accessed 12 September 2013).

Le Quéré, C., G. P. Peters, R. J. Andres, R. M. Andrew, T. A. Boden, P. Ciais, P. Friedlingstein, et al. 2014. « Global carbon budget 2013 ». Earth System Science Data 6 (1): 235-263. doi:10.5194/essd-6-235-2014.

Liu, X., and F. J. Millero. 2002. «The solubility of iron in seawater ». Marine Chemistry 77 (1): 43-54. doi:10.1016/S0304-4203(01)00074-3.

Lomas, M. W., A. L. Burke, D. A. Lomas, D. W. Bell, C. Shen, S.T. Dyhrman, and J. W. Ammerman. 2010. « Sargasso Sea phosphorus biogeochemistry: an important role for dissolved organic phosphorus (DOP) ». http://darchive.mblwhoilibrary.org:8080/handle/1912/3209.

Lønborg, C., and X. A. Álvarez-Salgado. 2012. « Recycling versus export of bioavailable dissolved organic matter in the coastal ocean and efficiency of the continental shelf pump: DOM bioavailability in the coastal ocean ». Global Biogeochemical Cycles 26 (3).doi:10.1029/2012GB004353.

Louis, J., M. Bressac, M. L. Pedrotti and C. Guieu. 2015. « Dissolved inorganic nitrogen and phosphorus dynamics in seawater following an artificial Saharan dust deposition event. » Frontiers in Marine Science 2:27. doi: 10.3389/fmars.2015.00027. 
Lucea, A., C. M. Duarte, S. Agustiand M.Søndergaard. 2003. «Nutrient (N, P and Si) and carbon partitioning in the stratified NW Mediterranean ». Journal of Sea Research 49 (3): 157-170. doi:10.1016/S1385-1101(03)00005-4.

Mahaffey, C., S. Reynolds, C. E. Davis, and M. C. Lohan. 2014. « Alkaline phosphatase activity in the subtropical ocean: insights from nutrient, dust and trace metal addition experiments ». Frontiers in Marine Science 1. doi:10.3389/fmars.2014.00073.

Marie, D., C. P. D. Brussaard, R. Thyrhaug, G. Bratbak, and D. Vaulot. 1999. «Enumeration of marine viruses in culture and natural samples by flow cytometry ». Applied and Environmental Microbiology 65 (1): 45-52.

Mari, X. 2008. « Does ocean acidification induce an upward flux of marine aggregates?». Biogeosciences, 5, 1023-1031, doi:10.5194/bg-5-1023-2008.

Marty, J.-C., J. Chiavérini, M.-D.e Pizay, and B.Avril. 2002. « Seasonal and interannual dynamics of nutrients and phytoplankton pigments in the western Mediterranean Sea at the DYFAMED time-series station (1991-1999) ». Deep Sea Research Part II: Topical Studies in Oceanography 49 (11): 1965-1985.

Maugendre, L., J.-P. Gattuso, A.J. Poulton, W. Dellisanti, M. Gaubert, C. Guieu, F. Gazeau, in press, this issue-a. « No detectable effect of ocean acidification on plankton metabolism in the NW oligotrophic Mediterranean Sea: results from two mesocosm studies ». Estuarine, Coastal and Shelf Science.

Maugendre, L., J.-P. Gattuso, A. De Kluijver, K. Soetaert, M. Gaubert, D. van Oevelen, J. Middelburg, F. Gazeau, in press, this issue-b. « Carbon-13 labelling studies show no effect of ocean acidification on carbon transfer in Mediterranean plankton communities ». Estuarine, Coastal and Shelf Science. 
McGill, D. A. 1965. «The relative supplies of phosphate, nitrate and silicate in the mediterranean sea ». Rapp. $P$-v. Reun.Comm. int. Explor. scient. Mer Mediterr. 18(3): $737-744$

MerMex Group, X. Durrieu de Madron, C. Guieu, R. Sempéré, P. Conan, D. Cossa, F. D’Ortenzio, et al. 2011. « Corrigendum to “Marine ecosystems' responses to climatic and anthropogenic forcings in the Mediterranean" ». Progress in Oceanography 91 (4): 97-166.

Millero, F. J. 1998. «Solubility of Fe (III) in seawater ». Earth and Planetary Science Letters $154, n^{\circ} 1: 323-29$.

Millero, F. J. 2009. «Effect of ocean acidification on the speciation of metals in seawater ». Oceanography 22 (4): 72-85.

Moutin, T., and P. Raimbault. 2002a. «Primary production, carbon export and nutrients availability in Western and Eastern Mediterranean Sea in early summer 1996 (MINOS cruise) ». Journal of Marine Systems, MATER: MAss Transfer and Ecosystem Response, 33-34: 273-288. doi:10.1016/S0924-7963(02)00062-3.

Moutin, T., T. F. Thingstad, F. Van Wambeke, D. Marie, G.Slawyk, P. Raimbault, and H. Claustre. 2002b. « Does competition for nanomolar phosphate supply explain the predominance of the Cyanobacterium Synechococcus? ». Limnology and Oceanography 47 (5): 1562-1567. doi:10.4319/lo.2002.47.5.1562.

Obata, H., H. Karatani, and E. Nakayama. 1993. « Automated determination of iron in seawater by chelating resin concentration and chemiluminescence detection ». Analytical Chemistry 65 (11): 1524-1528. doi:10.1021/ac00059a007.

Orr, J. C., V. J. Fabry, O. Aumont, L. Bopp, S. C. Doney, R. A. Feely, A. Gnanadesikan, et al. 
2005. «Anthropogenic ocean Acidification over the twenty-first century and its impact on calcifying organisms ». Nature 437 (7059): 681-686.

doi:10.1038/nature04095.

Pasqueron de Fommervault, O., C. Migon, F. D'Ortenzio, M. Ribera d'Alcalà, and L.Coppola. (2015). «Temporal variability of nutrient concentrations in the Northwestern Mediterranean Sea (DYFAMED time-series station) ». Deep Sea Research Part I: Oceanographic Research Papers 100: 1-12. doi:10.1016/j.dsr.2015.02.006.

Passow, U. 2012. « The abiotic formation of TEP under different ocean acidification scenarios ». Marine Chemistry 128-129: 72-80. doi:10.1016/j.marchem.2011.10.004.

Pujo-Pay, M., P. Conan, L. Oriol, V. Cornet-Barthaux, C. Falco, J.-F. Ghiglione, C. Goyet, T. Moutin, and L. Prieur. 2011. «Integrated survey of elemental stoichiometry (C, N, P) from the Western to Eastern Mediterranean Sea ». Biogeosciences 8 (4): 883-899. doi:10.5194/bg-8-883-2011.

Pulido-Villena, E., V. Rérolle, and C. Guieu. 2010. « Transient fertilizing effect of dust in Pdeficient LNLC surface ocean: fertilizing effect of dust in LNLC ocean ». Geophysical Research Letters 37 (1): L01603. doi:10.1029/2009GL041415.

Raimbault, P., W. Pouvesle, F. Diaz, N. Garcia, and R. Sempéré. 1999. « Wet-oxidation and automated colorimetry for simultaneous determination of organic carbon, nitrogen and phosphorus dissolved in seawater ». Marine Chemistry 66 (3-4): 161-169. doi:10.1016/S0304-4203(99)00038-9.

Ras, J., H. Claustre, and J. Uitz. 2008. « Spatial variability of phytoplankton pigment distributions in the Subtropical South Pacific Ocean: comparison between in situ and predicted data ». Biogeosciences 5 (2): 353-369. 
Raven, J., K. Caldeira, H. Elderfield, O. Hoegh-Gulderg, P. Liss, U. Riebesell, J. Shepherd, C.M. Turley, A. Watson. 2005. « Ocean Acidification due to Increasing Atmospheric Carbon dioxide». The Royal Society Policy Document, Cardiff.

Ridame, C., J. Dekaezemacker, C. Guieu, S. Bonnet, S. L'Helguen, and F. Malien. 2014. « Contrasted saharan dust events in LNLC environments: impact on nutrient dynamics and primary production ». Biogeosciences 11 (17): 4783-4800. doi:10.5194/bg-114783-2014.

Riebesell, U., J. Czerny, K. von Bröckel, T. Boxhammer, J. Büdenbender, M. Deckelnick, M. Fischer, et al. 2013. « Technical note: a mobile sea-going mesocosm system - new opportunities for ocean change research ». Biogeosciences 10 (3): 1835-1847. doi:10.5194/bg-10-1835-2013.

Romero, E., F. Peters, and C. Marras. 2012. «Dynamic forcing of coastal plankton by nutrient imbalances and match-mismatch between nutrients and turbulence ». Marine Ecology Progress Series 464: 69-87. doi:10.3354/meps09846.

Ruttenberg, K. C., and S. T. Dyhrman. 2012. «Dissolved organic phosphorus production during simulated phytoplankton blooms in a coastal upwelling system ». Frontiers in Microbiology 3. doi:10.3389/fmicb.2012.00274.

Sanders, R. W. 1991. « Mixotrophic protists in marine and freshwater ecosystems ». J. Protozool 38 (1): 76-81.

Schulz, K. G., U. Riebesell, R. G. J. Bellerby, H. Biswas, M. Meyerhöfer, M. N. Müller, J. K. Egge, et al. 2008. « Build-up and decline of organic matter during PeECE III ». Biogeosciences 5 (3): 707-718. 
Schulz, K. G., R. G. J. Bellerby, C. P. D. Brussaard, J. Büdenbender, J. Czerny, A. Engel, M. Fischer, et al. 2013. « Temporal biomass dynamics of an Arctic plankton bloom in response to increasing levels of atmospheric carbon dioxide ». Biogeosciences 10 (1): 161 - 180. doi:10.5194/bg-10-161-2013.

Shi, D., Y. Xu, B. M. Hopkinson, et F. M. M. Morel. 2010. «Effect of ocean acidification on iron availability to marine phytoplankton ». Science 327 (5966): 676-679. doi:10.1126/science.1183517.

Sintes, E., K. Stoderegger, V. Parada, and G. Herndl. 2010. « Seasonal dynamics of dissolved organic matter and microbial activity in the coastal North Sea ». Aquatic Microbial Ecology 60 (1): 85-95. doi:10.3354/ame01404.

Steinberg, D. K., C. A. Carlson, N. R. Bates, R. J. Johnson, A. F. Michaels, and A. H. Knap. 2001. « Overview of the US JGOFS Bermuda Atlantic Time-series Study (BATS): a decade-scale look at ocean biology and biogeochemistry ». Deep Sea Research Part II: Topical Studies in Oceanography 48 (8-9): 1405 - 1447. doi:10.1016/S09670645(00)00148-X.

Tanaka, T., T. F. Thingstad, U. Christaki, J. Colombet, V. Cornet-Barthaux, C. Courties, J.-D. Grattepanche, et al. 2011. «Lack of P-limitation of phytoplankton and heterotrophic prokaryotes in surface waters of three anticyclonic eddies in the stratified Mediterranean Sea ». Biogeosciences 8 (2): 525-538. doi:10.5194/bg-8-525-2011.

Thyssen, M., G. J. Grégori, J.-M. Grisoni, M. L. Pedrotti, L. Mousseau, L. F. Artigas, S. Marro, N. Garcia, O. Passafiume, and M. J. Denis. 2014. « Onset of the spring bloom in the Northwestern Mediterranean Sea: influence of environmental pulse events on the in situ hourly-scale dynamics of the phytoplankton community structure ». 
Frontiers in Microbiology 5. doi:10.3389/fmicb.2014.00387.

Touratier, F., and C. Goyet. 2011. «Impact of the Eastern Mediterranean Transient on the distribution of anthropogenic $\mathrm{CO}_{2}$ and first estimate of acidification for the Mediterranean Sea ». Deep Sea Research Part I: Oceanographic Research Papers 58 (1): 1-15. doi:10.1016/j.dsr.2010.10.002.

Witter, A. E., D. A. Hutchins, A. Butler, and G. W. Luther III. 2000. « Determination of conditional stability constants and kinetic constants for strong model Fe-binding ligands in seawater ». Marine Chemistry 69 (1-2): 1-17. doi:10.1016/S03044203(99)00087-0.

Yoshimura, T., J. Nishioka, K.Suzuki, H. Hattori, H. Kiyosawa, and Y. W. Watanabe. 2010. « Impacts of elevated $\mathrm{CO}_{2}$ on organic carbon dynamics in nutrient depleted Okhotsk Sea surface waters ». Journal of Experimental Marine Biology and Ecology 395 (1-2): 191-198. doi:10.1016/j.jembe.2010.09.001.

Zeebe, R. E. 2001. $\mathrm{CO}_{2}$ in Seawater: Equilibrium, Kinetics, Isotopes. Gulf Professional Publishing.

Zhang, J.-Zhong, and J. Chi. 2002. « Automated analysis of nanomolar concentrations of phosphate in natural waters with liquid waveguide ». Environmental Science \& Technology 36 (5): 1048-1053. doi:10.1021/es011094v.

Zimmer, L. A., and G. A. Cutter. 2012. «High resolution determination of nanomolar concentrations of dissolved reactive phosphate in ocean surface waters using long path liquid waveguide capillary cells (LWCC) and spectrometric detection ». Limnology and Oceanography: Methods 10: 568-580. doi:10.4319/lom.2012.10.568. 


\section{Figure captions}

Figure 1: Evolution of the concentration in chlorophyll a (Chla) and the abundance of heterotrophic prokaryotes (hetero. prokaryotes) along the course of the experiments in the Bay of Calvi (summer 2012) and Villefranche (winter 2013) outside and inside all mesocosms. The period between day -4 and day 0 corresponds to the acidification phase.

Figure 2: Evolution of the concentrations of inorganic and organic nutrients (nitrate + nitrite: $\mathrm{NO}_{\mathrm{x}}$, phosphate: $\mathrm{PO}_{4}{ }^{3-}$, dissolved organic nitrogen: DON and dissolved organic phosphorus: DOP) outside ('OUT') and inside all mesocosms along the course of the experiment in the Bay of Calvi in summer 2012.

Figure 3: Evolution of the concentrations of inorganic and organic nutrients (dissolved iron: $\mathrm{DFe}$, nitrate + nitrite: $\mathrm{NO}_{\mathrm{x}}$, phosphate: $\mathrm{PO}_{4}{ }^{3-}$, dissolved organic nitrogen: $\mathrm{DON}$ and dissolved organic phosphorus: DOP) outside ('OUT') and inside all mesocosms along the course of the experiment in the Bay of Villefranche in winter 2013. The period between day -4 and day 0 corresponds to the acidification phase.

Figure 4: Box-plots of nutrient concentrations (dissolved iron: $\mathrm{DFe}$, nitrate + nitrite: $\mathrm{NO}_{\mathrm{x}}$, phosphate: $\mathrm{PO}_{4}{ }^{3-}$, dissolved organic nitrogen: DON and dissolved organic phosphorus: DOP) measured during the experiments in the Bay of Calvi (BC) and in the Bay of Villefranche (BV). The statistical profile for "Control" was obtained as the daily mean value of the 3 controlmesocosms (C1, C2 and C3). The box-plot corresponds to $90 \%$ of data and the straight dark line represents the median value. The circles are the values considered statistically as outliers.

Figure 5: Relative mean deviation (MD; in \%) of the concentrations of inorganic and organic nutrients as a function of delta $\mathrm{pCO}_{2}(\mu \mathrm{atm})$ for each mesocosm at each time-point along the 
course of both experiments in the Bay of Calvi (BC) and in the Bay of Villefranche (BV). For each sampling date, the measured concentration in each perturbed mesocosm was subtracted from the arithmetic mean of concentrations in the 3 controls. The relative MD was estimated the ratio of this value to the mean concentration in the 3 control and expressed as a percentage. Delta $p \mathrm{CO}_{2}$ represents the difference in $p \mathrm{CO}_{2}$ level between the various treatments and the 3 controls for each time-point. Horizontal red lines correspond to the mean relative standard deviation of the 3 controls for each parameter over the duration of each experiment.

Figure 6: Average (all mesocosms) concentrations of chlorophyll $a$ (Chla; green line), nitrate + nitrite $\left(\mathrm{NO}_{\mathrm{x}}\right.$; red line), phosphate $\left(\mathrm{PO}_{4}{ }^{3-}\right.$; orange line) and heterotrophic prokaryotes (hetero. prokaryotes, grey line) along the course of the both experiments in the Bay of Calvi (BC) and in the Bay of Villefranche (BV). The color areas correspond to the range from minimum to maximum of $[\mathrm{Chl} a],\left[\mathrm{NO}_{\mathrm{x}}\right],\left[\mathrm{PO}_{4}{ }^{3-}\right]$ and hetero. prokaryotes measured. The period between day -4 and day 0 corresponds to the acidification phase.

Figure 7: Comparison of the evolution of the concentration of dissolved organic phosphorus (DOP) and the alkaline phosphate activity (APA) halfway through the experiment in the Bay of Calvi (BC). Sampling and analytical protocol for APA are described in Celussi et al. (in press, this issue).

Figure 8: Nitrate + nitrite $\left(\left[\mathrm{NO}_{\mathrm{x}}\right]\right) v s$ dissolved organic nitrogen $([\mathrm{DON}])(\mathrm{a}),\left[\mathrm{NO}_{\mathrm{x}}\right] v s$ ammonium $\left(\left[\mathrm{NH}_{4}^{+}\right]\right)(\mathrm{b})$, and $\left[\mathrm{NO}_{\mathrm{x}}\right]$ vs particulate organic carbon ([POC]) (c) during the experiment in the Bay of Villefranche (BV). Points represent all mesocosms data between day 3 and day 10 . The red line corresponds to the linear regression between $\left[\mathrm{NO}_{\mathrm{x}}\right]$ and $[\mathrm{POC}]\left(\mathrm{r}^{2}\right.$ $\left.=0.72, \mathrm{p}_{\text {value }}<0.001\right)$. 
Figure 9: Box-plot of the dissolved iron concentrations ([DFe]) for all mesocosms along the course of the experiment conducted in the Bay of Villefranche in winter 2013. The red line represents the linear regression of [DFe] (without outlier values) as a function of time between day 3 and day $7\left(r^{2}=0.62\right.$ and $\left.p_{\text {value }}<0.001\right)$ (a). Regression linear between [DFe] and the concentration of chlorophyll $a([\mathrm{Chl} a])$ between day 3 and day $7\left(\mathrm{r}^{2}=0.24\right.$ and $\mathrm{p}_{\text {value }}=$ 0.001) (b). 
Table 1. Initial (day 0) $p \mathrm{CO}_{2}(\mu \mathrm{atm})$ and $\mathrm{pH}_{\mathrm{T}}$ (total scale) conditions inside the nine mesocosms during the experiments in the Bay of Calvi in summer 2012 and in the Bay of Villefranche in winter 2013.

\begin{tabular}{|c|c|c|c|c|c|c|c|c|c|}
\hline Mesocosm experiment & $\mathrm{C} 1$ & $\mathrm{C} 2$ & $\mathrm{C} 3$ & $\mathrm{P} 1$ & $\mathrm{P} 2$ & P3 & $\mathrm{P} 4$ & P5 & P6 \\
\hline \multirow{2}{*}{ Bay of Calvi } & 474 & 465 & 462 & 609 & 731 & 790 & 920 & 1198 & 1353 \\
\hline & 8.01 & 8.02 & 8.02 & 7.92 & 7.85 & 7.82 & 7.76 & 7.66 & 7.61 \\
\hline \multirow{2}{*}{ Bay of Villefranche } & 378 & 347 & 350 & 494 & 622 & 690 & 743 & 932 & 1250 \\
\hline & 8.10 & 8.13 & 8.13 & 8.00 & 7.91 & 7.87 & 7.85 & 7.76 & 7.63 \\
\hline
\end{tabular}


Table 2. Initial (day 0) nutrients (dissolved iron: DFe, nitrate + nitrite: $\mathrm{NO}_{\mathrm{x}}$, phosphate: $\mathrm{PO}_{4}{ }^{3-}$, dissolved organic nitrogen: DON and dissolved organic phosphorus: DOP) and chlorophyll $a$ (Chla) concentrations inside the 3 'control' mesocosms (average and standard deviation calculated from the three independent measurements) for the Bay of Calvi (BC) and the Bay of Villefranche (BV) experiments. (*) When data on day 0 were not available, values have been measured on day 1.

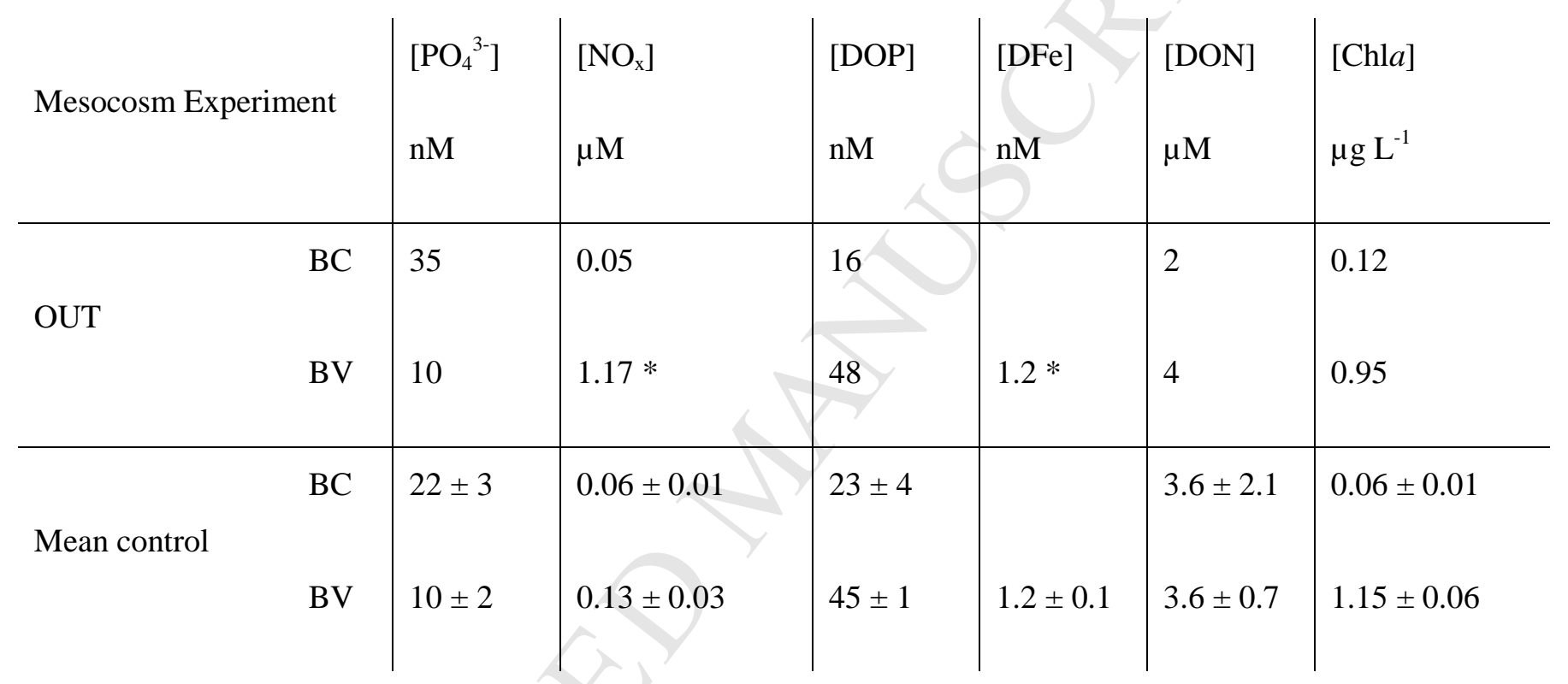


Table 3. Nitrate + nitrite $\left(\mathrm{NO}_{\mathrm{x}}\right)$, phosphate $\left(\mathrm{PO}_{4}{ }^{3-}\right)$, dissolved organic and total nitrogen (DON and TDN, respectively) and dissolved organic and total phosphate (DOP and TDP, respectively) concentrations and their ratio reported in the literature for the Mediterranean Sea. Values measured in this study correspond to data outside mesocosms at the beginning of both experiments. Several methods were used to DOP and DON: a) photo-oxidation UV; b) high temperature combustion; c) persulfate wet oxidation; d) UV-peroxide oxidation.

\begin{tabular}{|c|c|c|c|c|c|c|c|c|c|c|c|}
\hline \multirow{3}{*}{ Area } & \multirow{3}{*}{ Study } & \multirow{3}{*}{ Period } & \multirow{3}{*}{ Depth } & \multirow{3}{*}{$\begin{array}{l}{\left[\mathrm{NO}_{\mathrm{x}}\right]} \\
\mu \mathrm{M}\end{array}$} & \multirow{3}{*}{$\begin{array}{l}{\left[\mathrm{PO}_{4}{ }^{3-}\right]} \\
\mu \mathrm{M}\end{array}$} & \multirow{3}{*}{$\begin{array}{l}{[\mathrm{DON}]} \\
\mu \mathrm{M}\end{array}$} & \multirow{3}{*}{$\begin{array}{l}{[\mathrm{DOP}]} \\
\mu \mathrm{M}\end{array}$} & \multirow{3}{*}{$\frac{\left[\mathrm{NO}_{\mathrm{x}}\right]}{\left[\mathrm{PO}_{4}{ }^{3-}\right]}$} & \multirow{3}{*}{$\frac{[\mathrm{DON}]}{[\mathrm{DOP}]}$} & \multirow{2}{*}{$\begin{array}{l}{[\mathrm{DON}]} \\
{[\mathrm{TDN}]}\end{array}$} & \multirow{2}{*}{$\frac{[\mathrm{DOP}]}{[\mathrm{TDP}]}$} \\
\hline & & & & & & & & & & & \\
\hline & & & & & & & & & & $\%$ & $\%$ \\
\hline \multirow{7}{*}{$\begin{array}{l}\text { Western } \\
\text { basin }\end{array}$} & $T$ & June 2012 & $0-10 \mathrm{~m}$ & 0.05 & 0.03 & $2^{\mathrm{a}}$ & $0.02^{\mathrm{a}}$ & 1.7 & 100 & 98 & 40 \\
\hline & & February 2013 & $0-10 \mathrm{~m}$ & 1.17 & 0.01 & $4^{\mathrm{a}}$ & $0.05^{\mathrm{a}}$ & 117 & 80 & 78 & 83 \\
\hline & Coste et al. (1988) & Oct-Nov. 1981 & $5 \mathrm{~m}$ & 0.8 & 0.08 & $6.3 \mathrm{~d}$ & $0.13^{\mathrm{d}}$ & 10 & 48 & 89 & 62 \\
\hline & $\begin{array}{l}\text { Aminot and Kerouel } \\
\text { (1999) }\end{array}$ & Sept. 1984 & & nd & nd & $4.0-4.2^{\mathrm{c}}$ & $0.08^{\mathrm{d}}$ & nd & $55-57$ & nd & nd \\
\hline & Rimbault et al. (1999) & $\begin{array}{l}\text { Nov. 1997-March } \\
1998\end{array}$ & $0-160 \mathrm{~m}$ & nd & nd & $4.5-5.5^{c}$ & $0.06-0.1^{c}$ & nd & $43-88$ & nd & nd \\
\hline & Diaz et al. (2001) & March-April 1998 & $0-150 \mathrm{~m}$ & $\begin{array}{l}0.50- \\
1.80\end{array}$ & $<0.04$ & $4.32 \pm 0.42$ & $0.08 \pm 0.02$ & 68.4 & 75 & $70-90$ & $>70$ \\
\hline & $\begin{array}{l}\text { Moutin and Raimbault } \\
\text { (2002a) }\end{array}$ & May-June 1996 & $\begin{array}{l}0-100 \mathrm{~m} \\
<30 \mathrm{~m}\end{array}$ & $\begin{array}{l}1.2 \pm 1.4 \\
<0.05\end{array}$ & $\begin{array}{l}0.05 \pm 0.05 \\
<0.02\end{array}$ & $\begin{array}{l}4.6 \pm 0.6^{c} \\
\text { nd }\end{array}$ & $\begin{array}{l}0.08 \pm 0.02^{c} \\
\text { nd }\end{array}$ & $\begin{array}{l}\sim 22 \\
\text { nd }\end{array}$ & $\begin{array}{l}58 \\
\text { nd }\end{array}$ & $\begin{array}{l}\sim 80 \\
\text { nd }\end{array}$ & $\begin{array}{l}62 \\
\text { nd }\end{array}$ \\
\hline
\end{tabular}




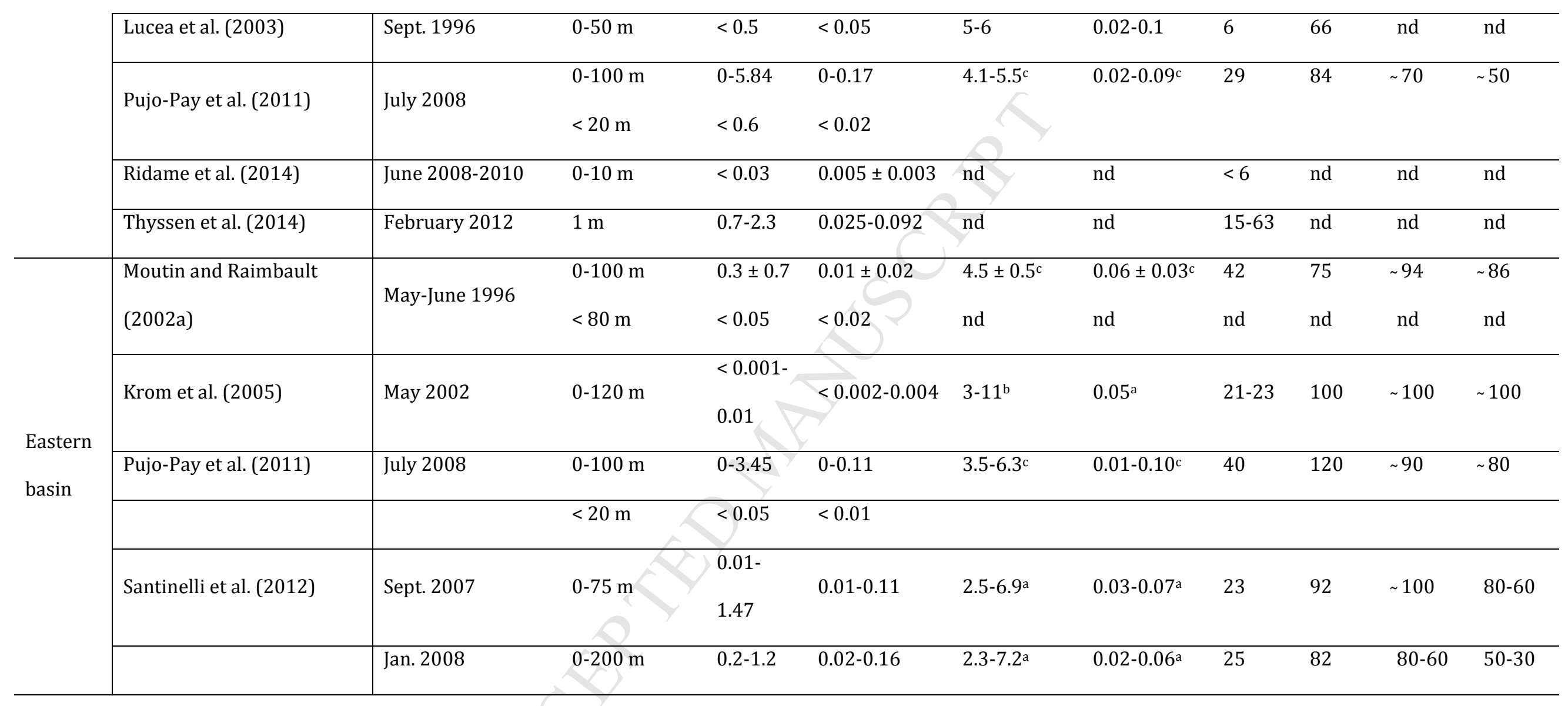


Figure 1 :
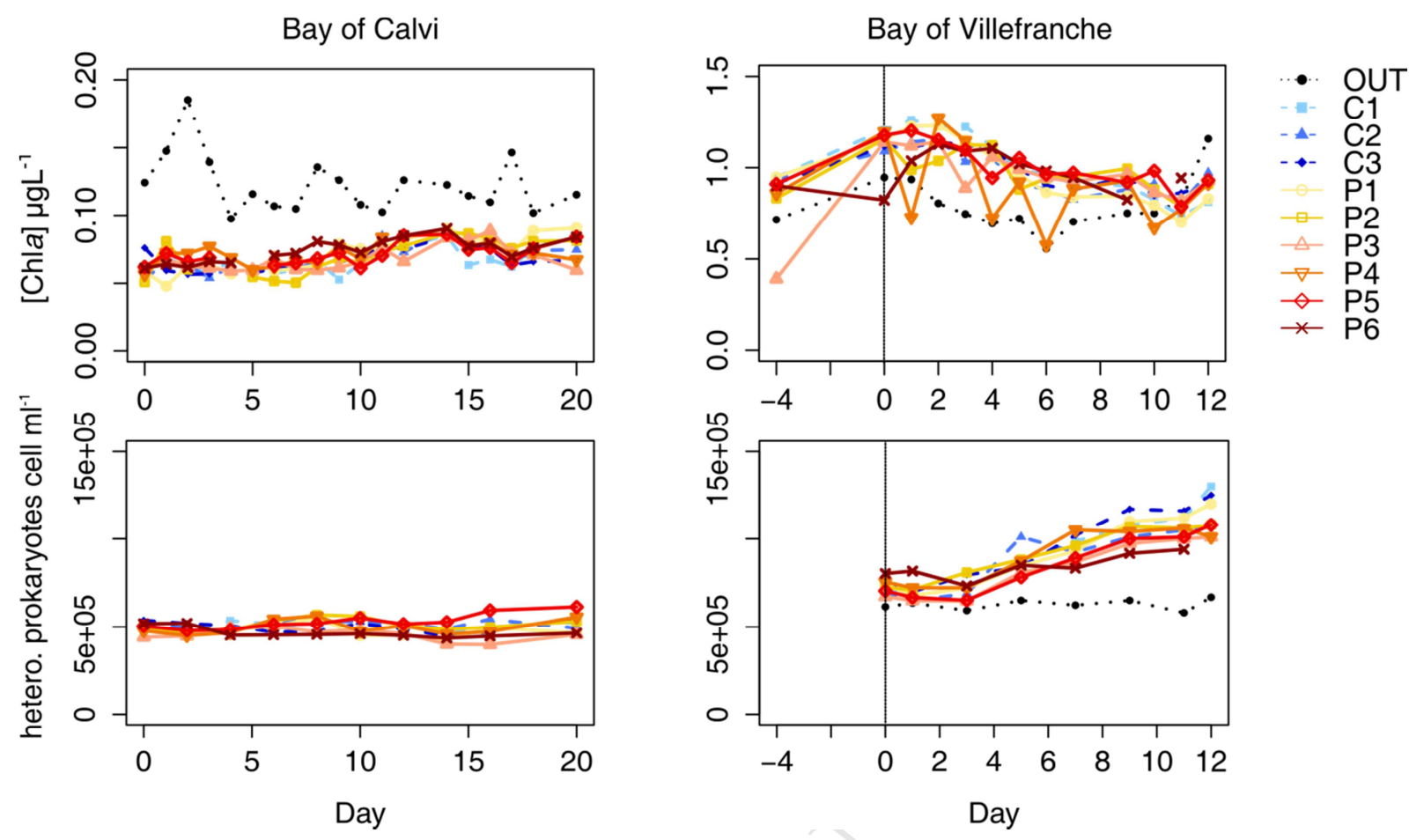

Figure 2 :
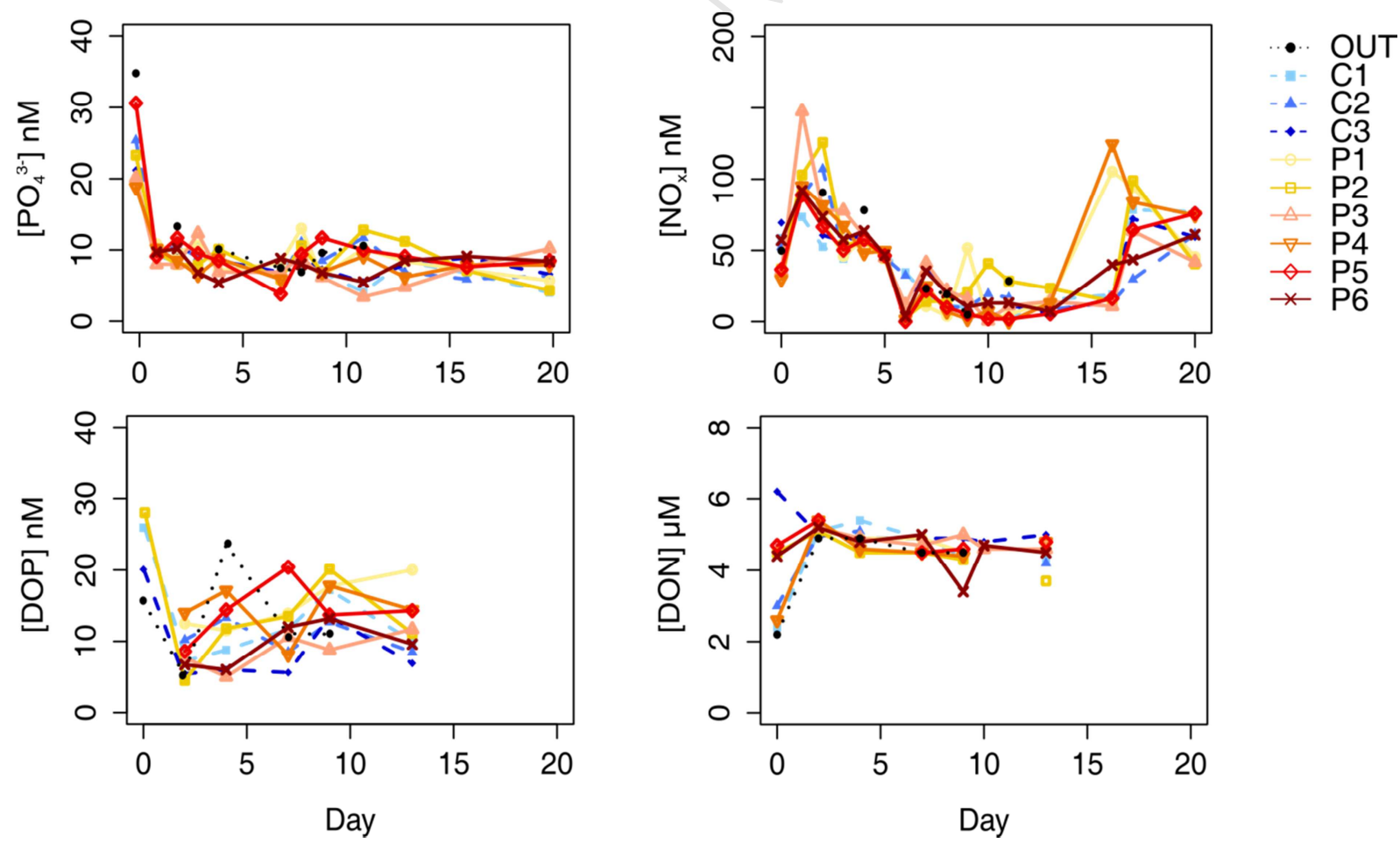
Figure 3 :
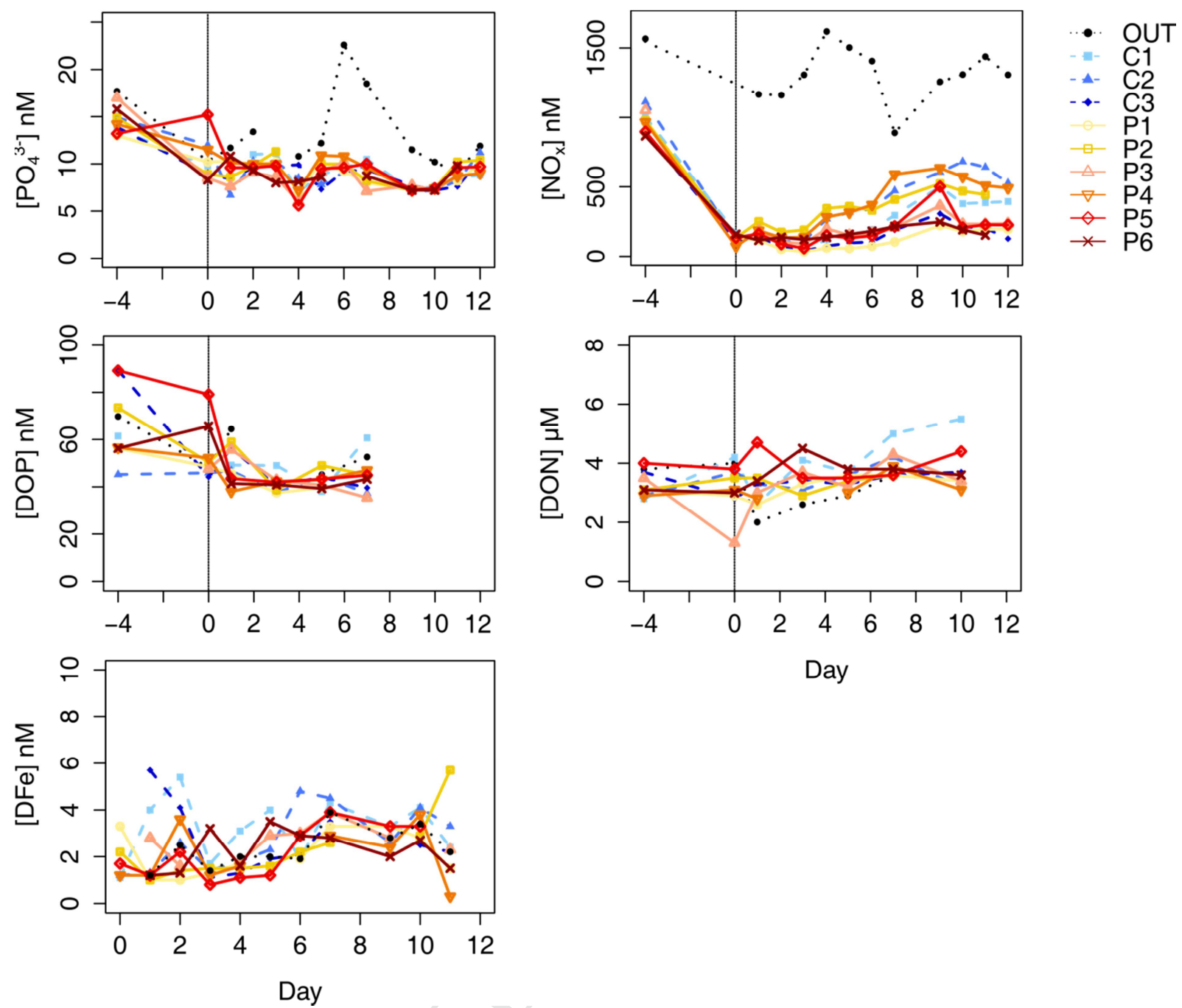

Day 
Figure 4 :
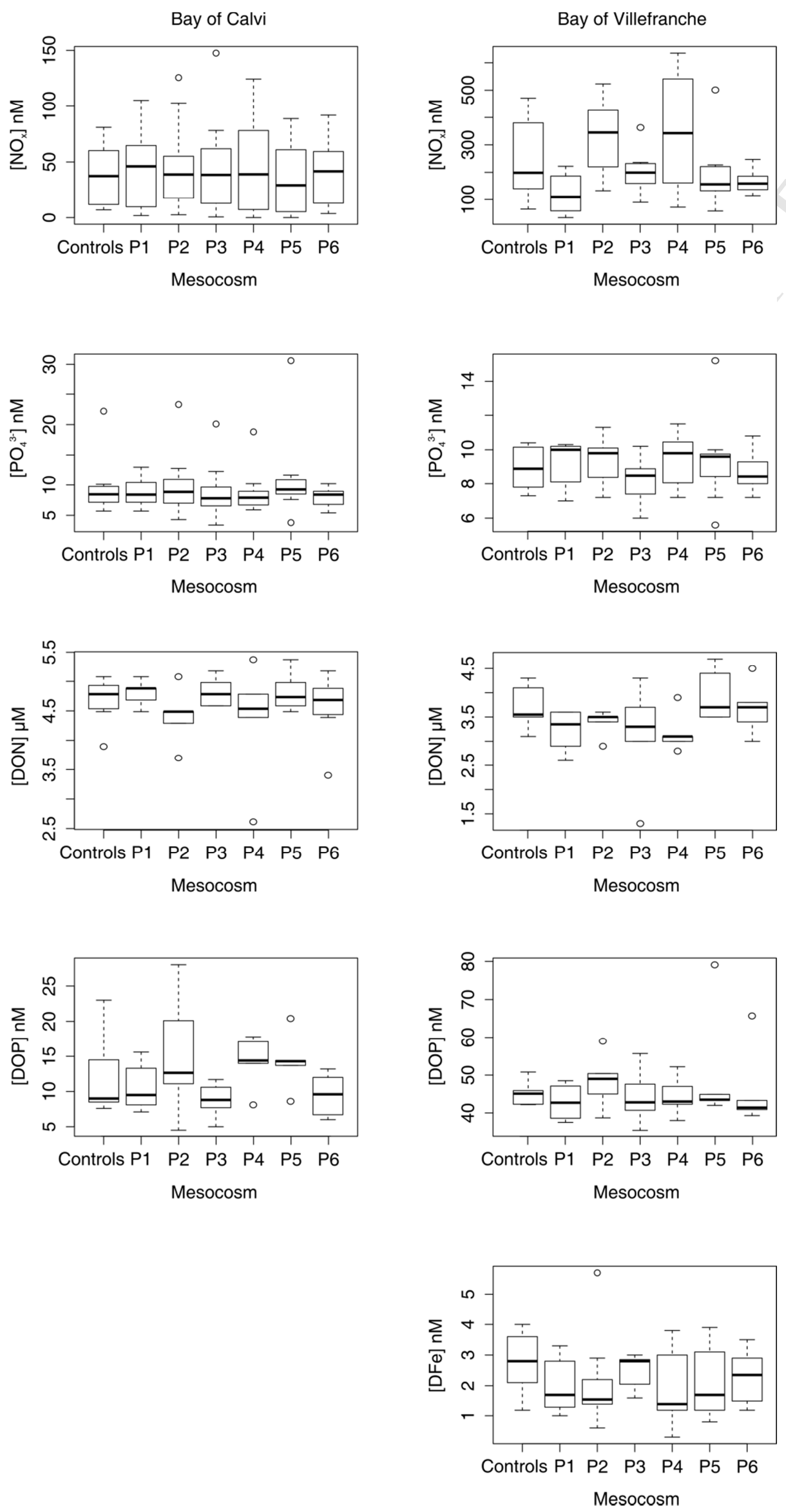
Figure 5 :

Bay of Calvi
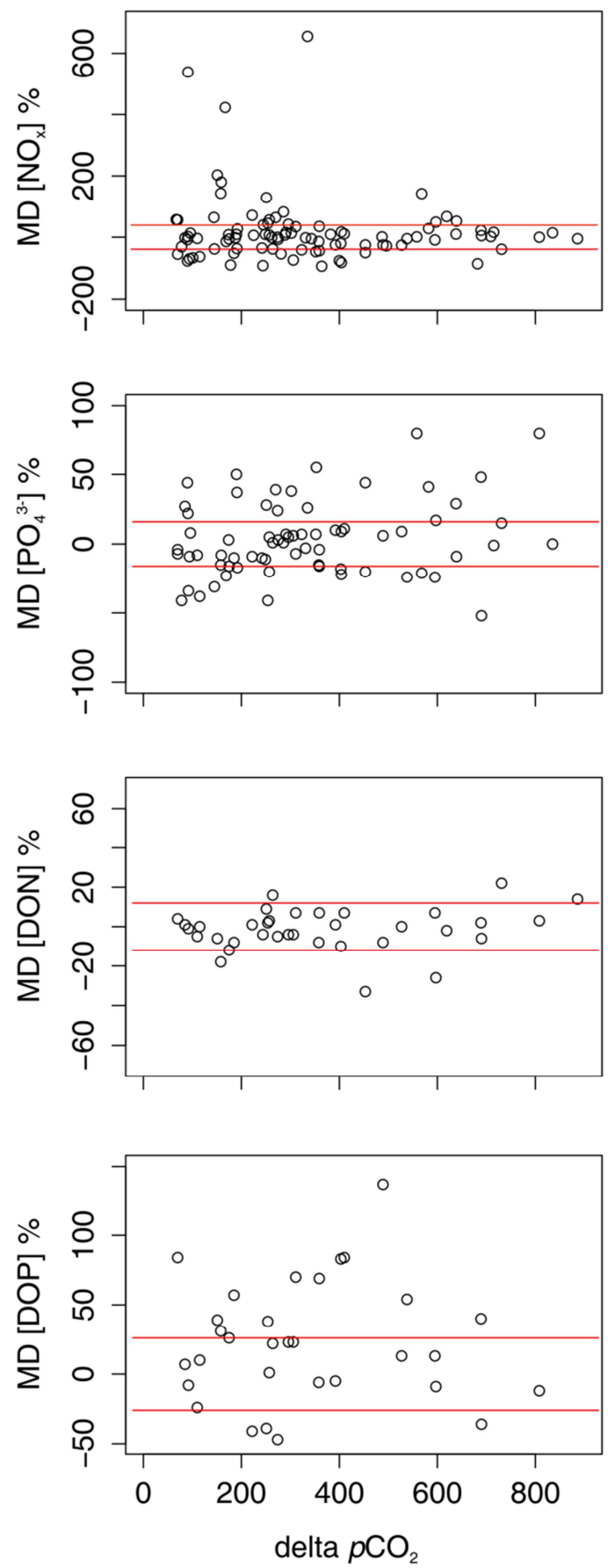

Bay of Villefranche
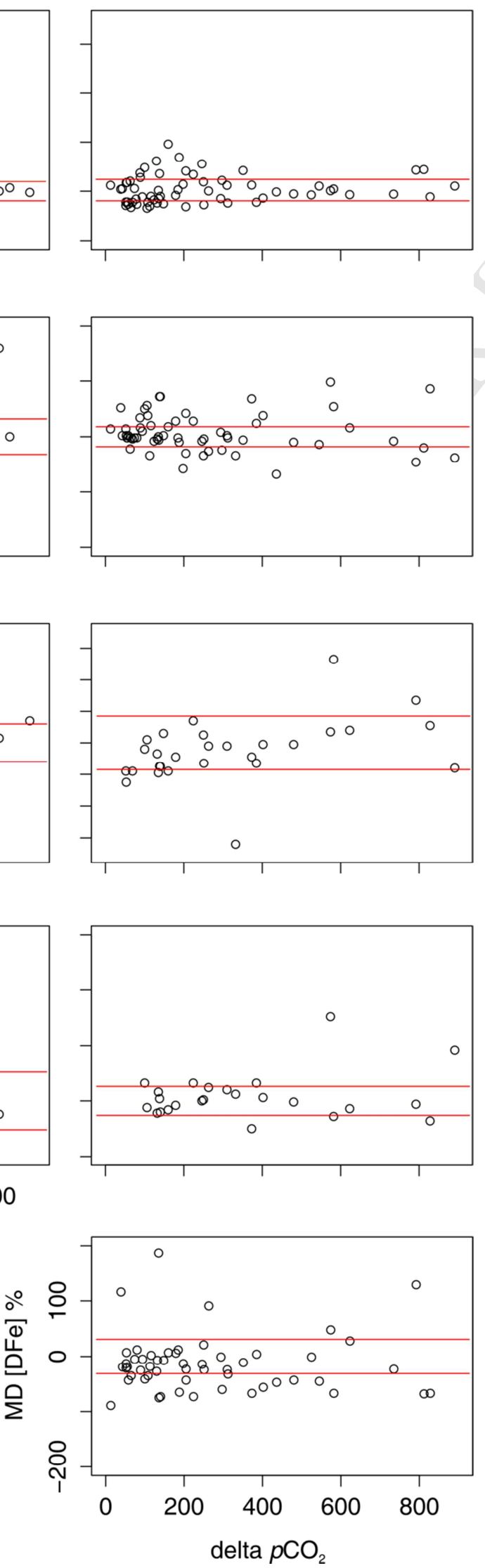
Figure 6 :
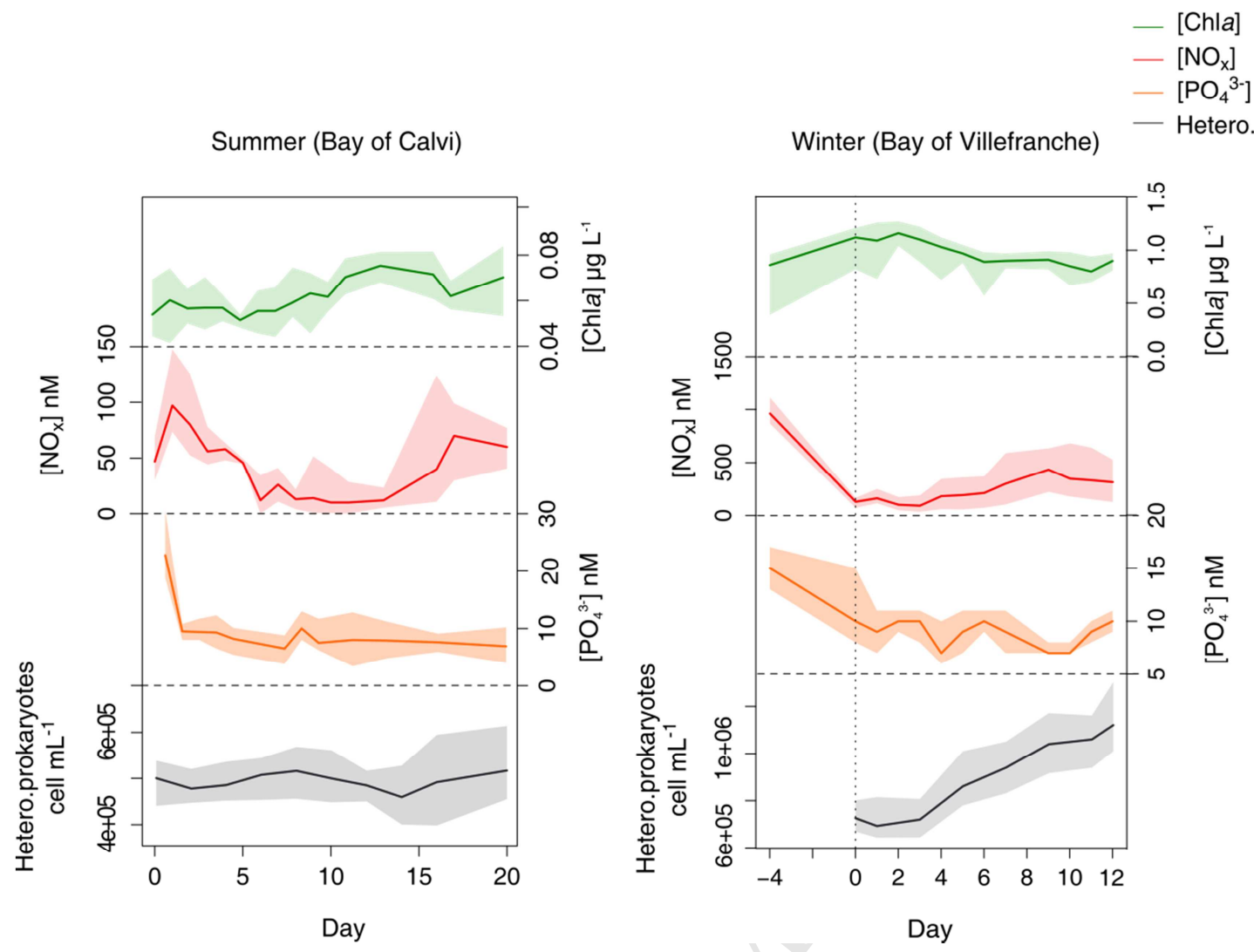

Figure 7 :

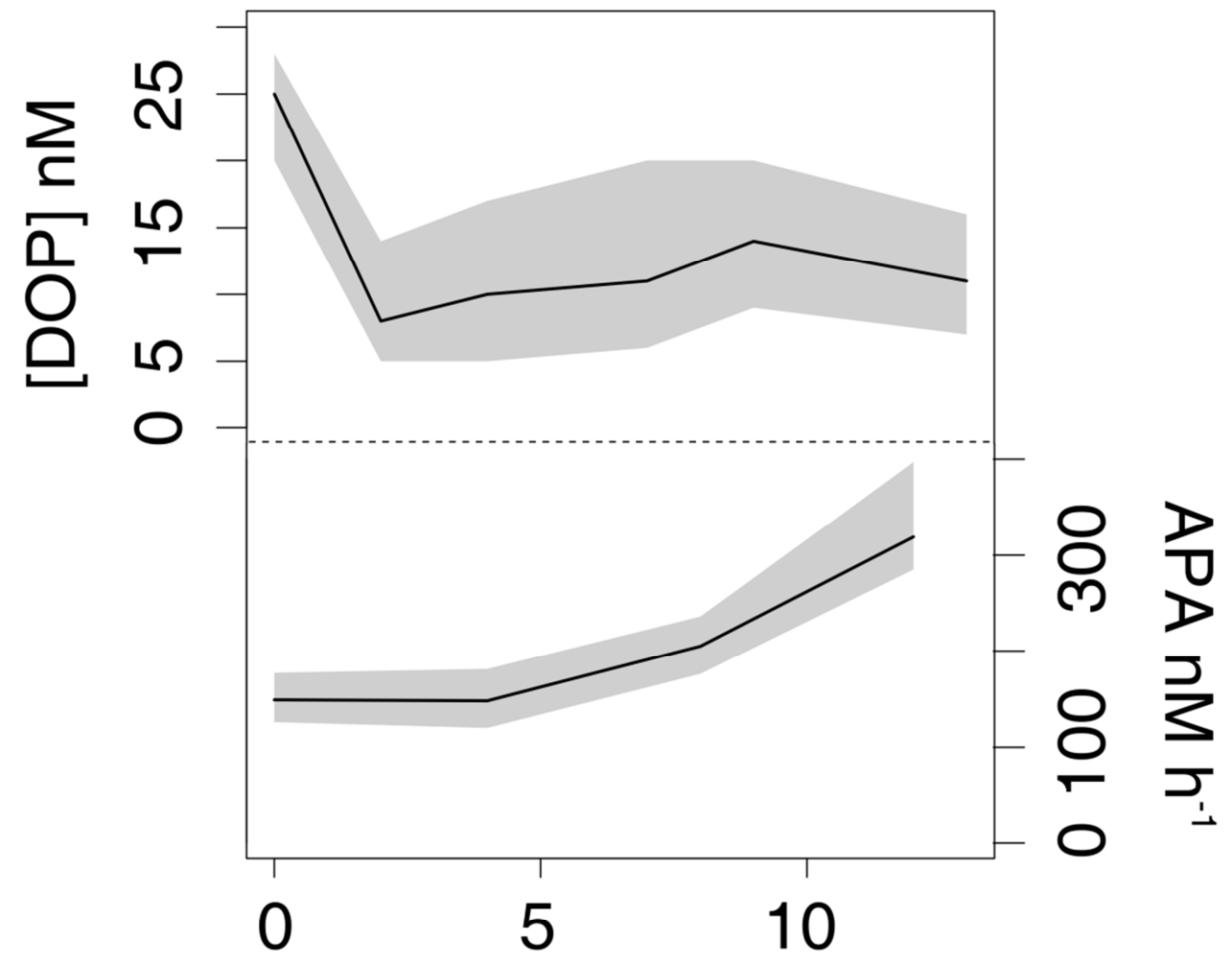

Day 
Figure 8 :
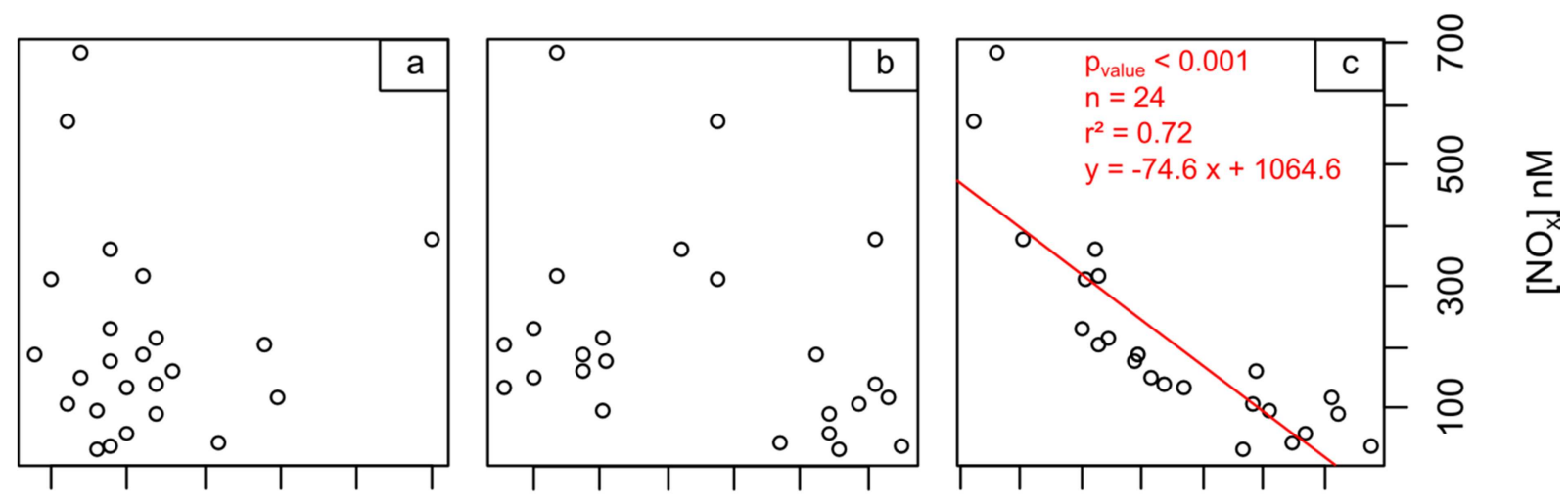

$\begin{array}{lllllllll}3.0 & 3.5 & 4.0 & 4.5 & 5.0 & 5.5 & 0.030 & 0.040 & 0.050\end{array}$

$\begin{array}{lllll}8 & 9 & 10 & 12 & 14\end{array}$

[DON] $\mu \mathrm{M}$

$\left[\mathrm{NH}_{4}^{+}\right] \mu \mathrm{M}$

[POC] $\mu \mathrm{M}$

Figure 9 :
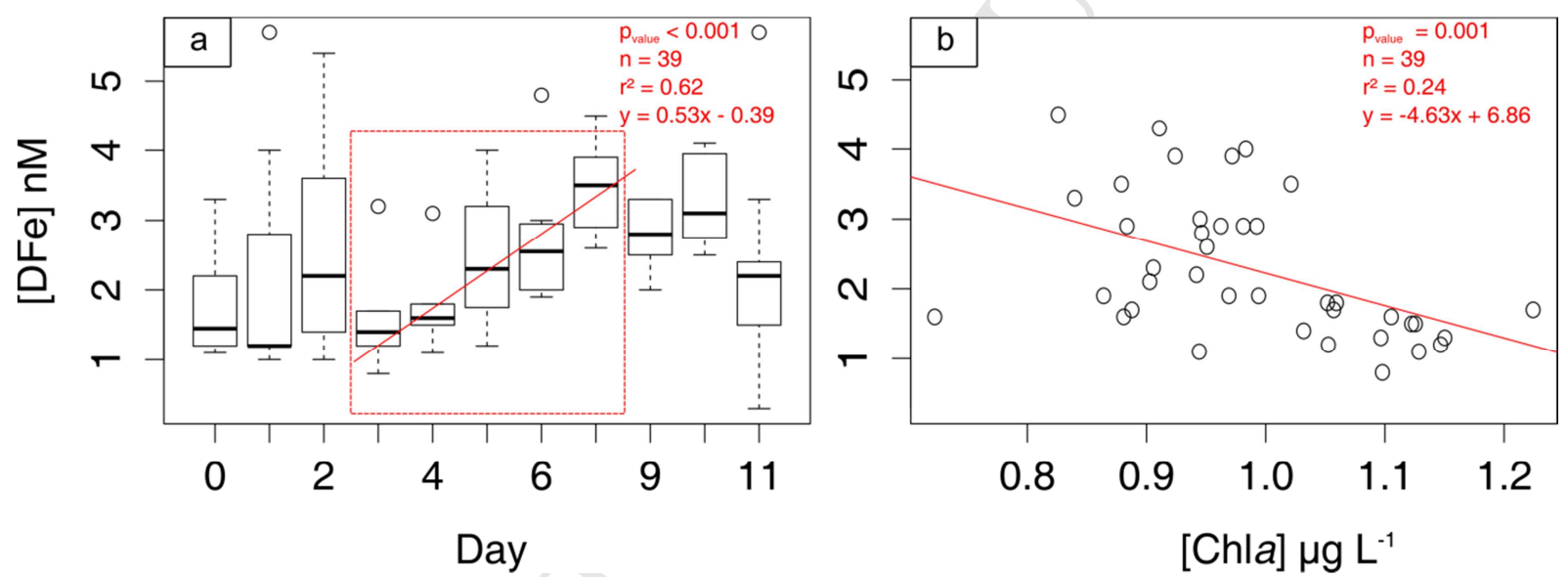